\title{
Low-frequency glow discharge (LFGD) plasma treatment enhances maize (Zea mays L.) seed germination, agronomic traits, enzymatic activities, and nutritional properties
}

\author{
Md. Sohanur Rahman Sohan ${ }^{1}$, Mahedi Hasan ${ }^{1}$, Md. Forhad Hossain ${ }^{1}$, Salek Ahmed Sajib, \\ Khandaker Md. Khalid-Bin-Ferdaus ${ }^{1}$, Ahmad Humayun Kabir ${ }^{2}$, Md. Mamunur Rashid ${ }^{3}$, \\ Mamunur Rashid Talukder ${ }^{3}$, Mona M. Elseehy ${ }^{4}$, Ahmed M. El-Shehawi ${ }^{5}$ and Md Abu Reza ${ }^{1 *}$ (D)
}

\begin{abstract}
Background: Plasma technology is an emerging sector in agriculture. The effect of low-frequency glow discharge (LFGD) plasma at medium pressure (10 torr) on maize morpho-physiological and agronomical behavior was investigated in the current studies. The LFGD plasma act as a secondary messenger to improve maize production. This cutting-edge plasma technology can be used in agriculture to boost agronomic possibilities.
\end{abstract}

Materials and methods: Maize seeds were treated with LFGD Ar+Air gas plasma for $30 \mathrm{~s}, 60 \mathrm{~s}, 90 \mathrm{~s}$, and $120 \mathrm{~s}$. The gas ratio of Ar + Air was 1:99. Plasma was produced with a high voltage (1-6 kV) and low (3-5 kHz) frequency power supply across the electrodes. The internal pressure was maintained at $\sim 10$ torrs with a vacuum pump in the plasma chamber. Inside the plasma production chamber, the gas flow rate was maintained at $1 \mathrm{~L} / \mathrm{min}$.

Results: Effect of LFGD Ar + Air plasma on seed germination, and growth parameters including, shoot length, root length, fresh weight, dry weight, plant height, stem diameter, and chlorophyll were measured and in comparison with the control the parameter scores increased by 4.89\%, 3.18\%, 1.77\%, 5.53\%, 1.90\%, 5.16\%, 1.90\%, 1.98\%, respectively. The SEM image of the seeds surface demonstrated remarkable changes caused by plasma treatment. In roots, APX and SOD activities improved by only $0.022 \%$ and $0.64 \%$, whereas, in shoots their activities showed a $0.014 \%$ and $0.25 \%$ increment compared to control. Further, $\mathrm{H}_{2} \mathrm{O}_{2}$, soluble protein, and sugar content increased by $0.12 \%, 0.33 \%, 2.50 \%$ and $1.15 \%, 1.41 \%, 2.99 \%, 1.16 \%$ in shoots and roots, respectively, while NO showed no significant changes in plants. Interestingly, notable improvement were found in nutritional properties (protein $0.32 \%$, fat $0.96 \%$, fiber $0.22 \%$, ash $0.31 \%$, grain iron $1.77 \%$, shoots iron $7.61 \%$, and manganese $6.25 \%$ ), while the moisture content was reduced by $0.93 \%$ which might be useful in prolonged seed storage and the long life viability of the seeds. However, zinc (Zn) content in maize seedlings from plasma-treated seeds showed no significant change.

Conclusion: The present study revealed that LFGD Ar + Air gas plasma is associated with the elevation of ROS in leaves and roots, which in turn improves the seed germination rate, agronomic traits, growth, enzymatic activity, and nutritional supplement in maize.

\footnotetext{
*Correspondence: reza.gen@ru.ac.bd

${ }^{1}$ Molecular Biology and Protein Science Laboratory, Department of Genetic Engineering and Biotechnology, University of Rajshahi, Rajshahi 6205, Bangladesh

Full list of author information is available at the end of the article
}

(C) The Author(s) 2022 Open Access This article is licensed under a Creative Commons Attribution 4.0 International License, which permits use, sharing, adaptation, distribution and reproduction in any medium or format, as long as you give appropriate credit to the original author(s) and the source, provide a link to the Creative Commons licence, and indicate if changes were made. The images or other third party material in this article are included in the article's Creative Commons licence, unless indicated otherwise in a credit line to the material. If material is not included in the article's Creative Commons licence and your intended use is not permitted by statutory regulation or exceeds the permitted use, you will need to obtain permission directly from the copyright holder. To view a copy of this licence, visit http://creativecommons.org/licenses/by/4.0/. The Creative Commons Public Domain Dedication waiver (http://creativeco mmons.org/publicdomain/zero/1.0/) applies to the data made available in this article, unless otherwise stated in a credit line to the data. 


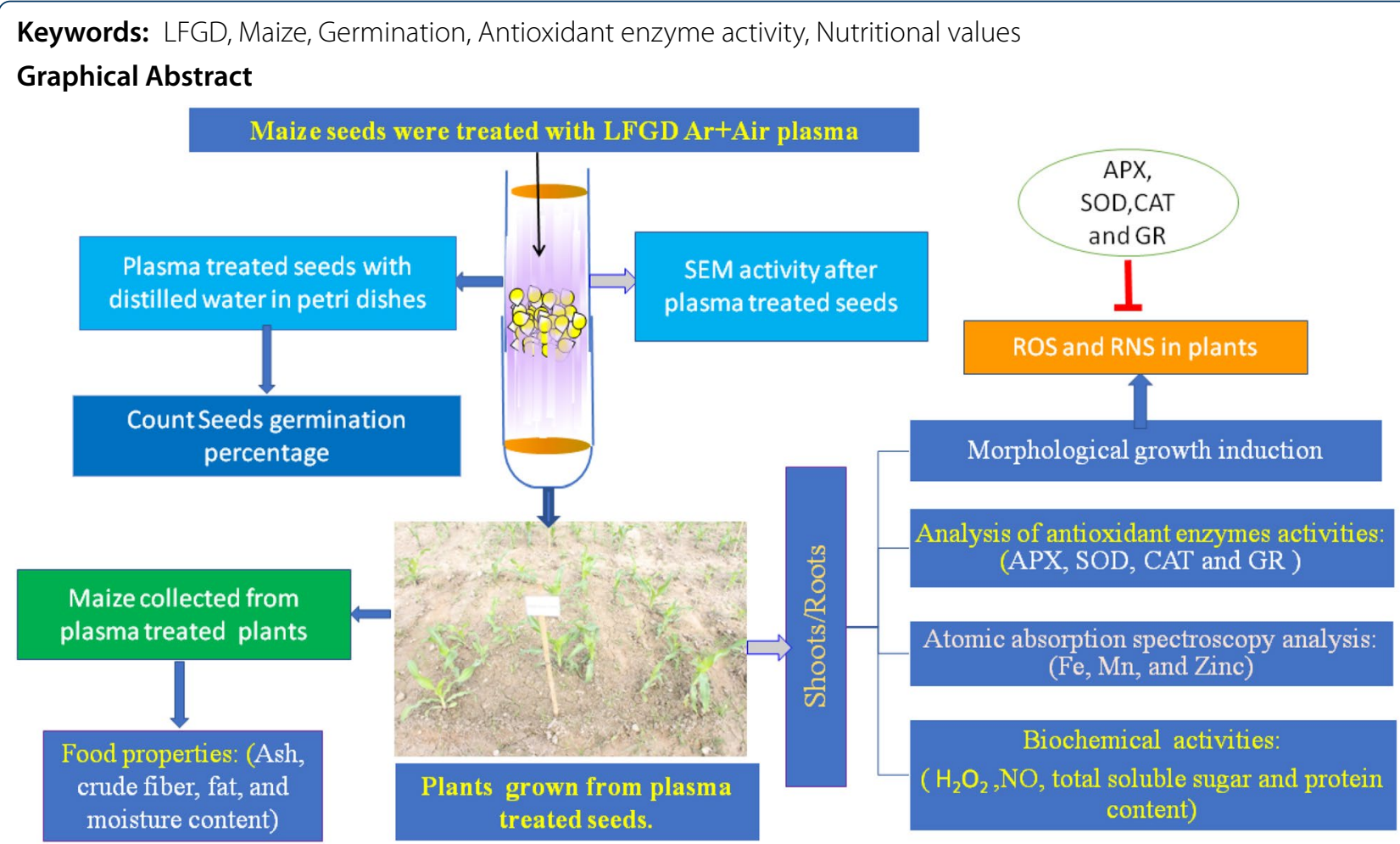

\section{Background}

Crop production is under threat in several countries around the world due to speedy industrialization, urbanization, overpopulation, and reducing agricultural lands [1]. Day by day, the production of maize is decreasing due to climate change and man-made factors [2]. Moreover, the reduction of productivity of crops is due to the reduction of macro and micronutrients in the soil [3]. Maize (Zea mays L.) is a leading staple food in many countries, especially in European countries, and the majority of farmers grow maize as a stand-alone crop in their field [4]. Maize can be considered as an alternative food source in Bangladesh and subtropical countries, which contains a higher level of protein, minerals, and fatty acids. It has been used in the production of ethanol, corn starch, and corn syrup in many other countries [5]. Maize is the third-largest crop in Bangladesh, according to acreage along with production. Crop production and food security are vastly reliant on seed quality such as seed germination, vigor, and volume [6]. Pesticides and chemical fertilizers are widely used all over the world for increased production of crop plants, although they have adverse impacts on health, ecosystems, and the environment [7]. Therefore, new techniques and technology having the capability of increasing crop yields and improving nutritional values without environmental risks are currently being focused on in agricultural areas.

Plasma treatment is a new technology, which recently gained huge attention in the agricultural sector. Plasma has essential roles in different areas such as microelectronic technology, medicine, fusion power, and ion implantation for material adaptation [8, 9]. Medium pressure of low-frequency glow discharge plasma (LFGD) is a source of non-thermal plasma, generated in the laboratory under medium pressure ( 10 torr) with a high voltage and low frequency. Several studies have shown that plasma treatment is a fast, cheap, riskless, pollution-free method used to increase seed quality, seedling growth, and production [10]. Enhancing maize grain output has been a major focus of plant breeding and genetic engineering in order to fulfill worldwide demand for food, fodder, poultry-dairy farm feed, and industrial usage [11].Techniques such as solar radiation, weather optimization, variety creation using conventional breeding as well as genetic engineering, and so on are used to boost maize growth [12]. Recent studies show that plasma treatment plays a vital role in both plant development and the physiological processes of plants, along with the seed germination rate, seedling growth [2], and photosynthesis activation of plants [13]. Atmospheric pressure cold plasmas (APCPs) are 
highly effective instruments for improving seed germination by using water absorption processes [14]. Cold plasma is also a promising tool in medical science, with an argon-based plasma jet being used for both in vivo and in vitro cancer treatment [15]. Plasma treatment has also been shown to raise plant yields under biotic and abiotic stress, such as disease [16] and drought stress [8]. Further, low-frequency glow discharge plasma technology can play a positive role in disease control, which can be an alternate use for fertilizers and pesticides in the agricultural sector. The plasma technique is a novel device that has demonstrated its value in improving agronomic individuality in a variety of crops [17]. Plasmas may also be utilized to efficiently clean and sterilize air and water [18].

Plasma is an ionized gas composed of charged particles (electrons, ions), excited atoms and molecules, reactive species (ROS, RNS), and UV photons. The excessive amount of ROS and RNS which is deleterious to maize seeds and less than certain an amount may not generate adequate for biochemical and/or biophysical triggering. In plants, there are several defense mechanisms against various stresses; among them the antioxidant is activated first. In addition, earlier reports stated that antioxidant enzyme activity such as catalase (CAT) and superoxide dismutase (SOD) [8] is significantly increased due to plasma treatment and regulates ROS and RNS activities [19]. Also, plasma treatment can increase the seed wettability and seed germination [20]. $\mathrm{H}_{2} \mathrm{O}_{2}$ plays a dual role in plants, which depends on several conditions, including physiological conditions, application, and specification [21]. By triggering the $\mathrm{H}_{2} \mathrm{O}_{2}$ scavengers (APX, SOD, CAT and GR), LFGD plasma may regulate the reactive oxygen species. $\mathrm{H}_{2} \mathrm{O}_{2}$ is also considered as a signaling molecule for breaking the seed dormancy and antioxidant protection in plants [1]. Still, it is challenging to optimize the reactive oxygen species in the discharge that might produce superior reactive oxygen species such as superoxide anion $\left(\mathrm{O}_{2}{ }^{-}\right)$, hydroxyl radical $(. \mathrm{OH})$, and $\mathrm{H}_{2} \mathrm{O}_{2}$ [1]. Reactive oxygen species cause cell fatality, membrane scratch, and degradation of protein in plants [22]. Nitric oxide (NO) is another bio-reactive signaling molecule that is responsible for the control and regulation of plant development in many stages [23]. NO plays a crucial part in the breach of seed dormancy and germination $[24,25]$.

Plasma technology has already demonstrated that LFGD plasma improves wheat seed germination and seedling growth [26]. The current study focused on field trials, and we wanted to see the changes in traits in next-generation plants grown from plasma-treated maize seeds. Therefore, we performed a series of morphological, molecular and biochemical, experiments to elucidate the effect and mechanism of LFGD plasma mediated improvement seed germination, plant growth, and nutritional changes in maize.

\section{Materials and methods \\ Plasma generating setup}

Two copper electrodes (10 $\mathrm{mm}$ in diameter) were placed at the lower and upper ends of the Pyrex glass tube, which contained maize seeds for low-frequency glow discharge plasma treatment as shown in Fig. 1. The spacing between two copper electrodes were maintained at $80 \mathrm{~mm}$. Plasma was created by combining a medium pressure ( $\sim 10$ torr) power supply with a high voltage $1-6 \mathrm{kV}$ and low frequency $(3-5 \mathrm{kHz})$ across the electrodes. The pressure inside the plasma chamber was maintained at $\sim 10$ torr using a vacuum pump (FY-1C, Jiangsu Jindong HVAC Industrial Co. Ltd., China). The flow of Ar + Air gas was controlled by two gas flow indicators (Yamato Scientific Co. Ltd., Tokyo, Japan). The gas flow rate inside the plasma production chamber was maintained at $1 \mathrm{~L} /$ minute. Gas and seed surface temperatures for $120 \mathrm{~s}$ treatment were $\sim 40{ }^{\circ} \mathrm{C}$ and $\sim 27^{\circ} \mathrm{C}$, respectively, which was measured through an IRT25 Infrared Thermometer (Extech, Nashua, NH 03063, USA). The proportion of the gas between argon (Ar) and air was 1:99. The discharge of voltage and current were monitored with voltage (HVP-08) and current (CP-07C) probes, respectively, which was connected with four-channel digital storage oscilloscope (GDS-1000B, Good Will Instrument Co., Taiwan). The spectrophotometer USB2000 + XR - 1 - ES (Ocean optics, Taiwan; slit size of $25 \mu \mathrm{m}$, grating 800 line $/ \mathrm{mm}$, optical resolution, $1.7 \mathrm{~nm}$ ) was used for species identification, which ranged from 200 to $1100 \mathrm{~nm}$, and the duel channel spectrophotometer, AvaSpec-2018 (Avantes, Apeldoorn, Netherlands; slit: $10 \mu \mathrm{m}$, grating: 2400 lines $/ \mathrm{mm}$, optical resolution: $0.07 \mathrm{~nm}$ ) was used in the range from 200 to $500 \mathrm{~nm}$ for the determination of plasma parameters.

\section{Seed treatment}

Maize (Zea mays L.) seeds were collected from the local market at katakali Bazar, Rajshahi, Bangladesh. Healthy and uniform maize seeds were selected visually with the help of a simple magnifying glass for control and treatment. Seeds were treated by LFGD plasma generated from Ar + air gas in the Plasma Science and Technology Lab, Department of Electrical and Electronic Engineering, University of Rajshahi. Maize seeds were placed into the plasma generating chamber for treatment. Plasma treatment was applied to the seeds for different time duration viz. $30 \mathrm{~s}, 60 \mathrm{~s} 90 \mathrm{~s}$ and $120 \mathrm{~s}$. 


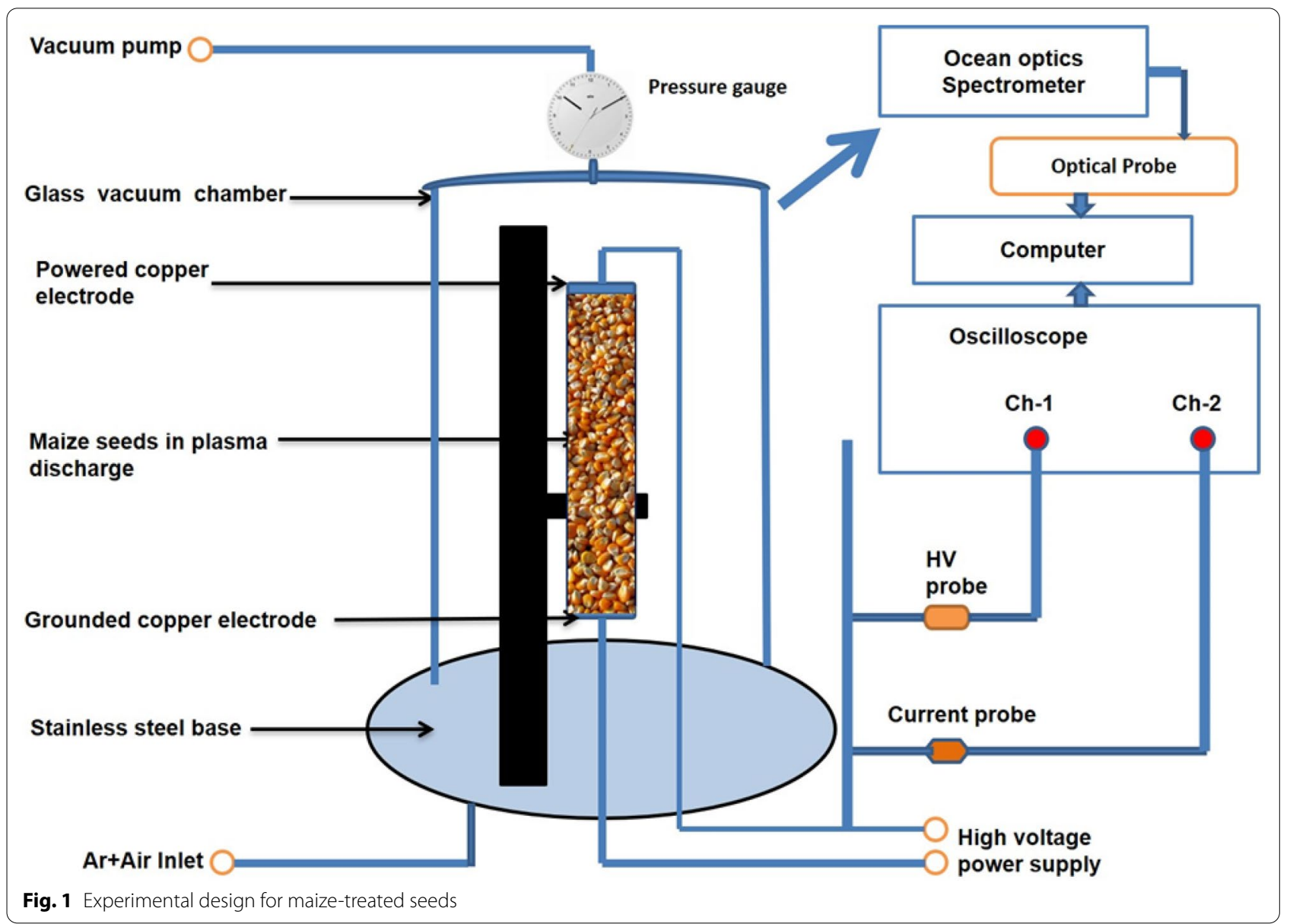

Field preparation for maize cultivation

The experiment was performed in the research field of the Department of Genetic Engineering and Biotechnology, Faculty of Life and Earth Science, University of Rajshahi (Latitude: 24.37047 Longitude: 88.64904 N $\left.24^{\circ} 22^{\prime} 13.67486^{\prime \prime} \mathrm{E} \quad 88^{\circ} 38^{\prime} 56.5323^{\prime \prime}\right)$ in Bangladesh. 0.027 ha (6.6 decimal) soil was selected for this experimental study. The field was prepared by horizontal, centrally balanced with uniform land fertility and was divided into 15 plots. 12 plots were selected for treated seeds, and 3 plots were used for untreated seeds using the randomized block design. Size of each plot was $2 \times 2$ $\mathrm{m}^{2}$ with $72 \mathrm{~cm}$ line-line spacing, and three independent replications were used in this study for every treatment and control. Both treated and untreated seeds were sown in the respective plot on December 01.12, 2018.

\section{Scanning electron microscopic (SEM)}

For investigating the changes on seed surface topology, structure and overall surface features, the control and plasma-treated seeds were studied under scanning electron microscope (FEI S50, FEI Technologies Inc., Oregon, United States). For scanning electron microscopy seeds treated for $90 \mathrm{~s}$ and $120 \mathrm{~s}$ were used. As control, untreated seeds were used which have gone through the identical conditions except the plasma treatment. Images were captured at the microscopic magnification of $1000 \mathrm{X}$ with $10 \mathrm{kV}$ accelerating voltage and $20 \mu \mathrm{m}$ in secondary electron scanning mode.

\section{Germination rate and morpho-physiological characterization}

Control and plasma-treated seeds $(N=30)$ were placed on a wet Whatman grade-1 filter paper in $90 \mathrm{~mm}$ petri dishes. The petri plates were incubated at $25{ }^{\circ} \mathrm{C}$ in an incubator for 7 days. Distilled water was sprinkled twice a day to maintain adequate moisture content for seed germination. The standard that was followed to determine the seed germination was germ length when it reached half or above of the seed length. The percentage of germination rate (\%) was calculated after 7 days by the following formula: 
Germination rate $(\%)=$ Number of total seeds germination after 7days/Total number of seeds $\times 100$.

Upon maturation, the fresh plants were collected from the experimental field after 45 days of plantation for morphological data collection. Morphological parameters were recorded via a tailoring tape, slide calipers, and digital weighing balance. The total chlorophyll score in young leaves were determined using a leaf chlorophyll meter (FT GREEN, USA). Randomly picked young fresh leaves were collected from the experimental field for the reading the chlorophyll score.

\section{Analysis of antioxidant enzymes (CAT, SOD, APX, and GR)} Antioxidant enzyme activities were determined as described previously [1] with slight modifications. In brief, the fresh tissues were collected and mashed with a mortar and pestle in $1 \mathrm{ml}$ phosphate buffer $(100 \mathrm{mM}$, $\mathrm{pH} 7,0)$. These leaf tissue extracts were centrifuged at $12,000 \mathrm{rpm}$ for $5 \mathrm{~min}$ and subsequently supernatant was transferred into a new microcentrifuge tube. For catalase (CAT) activity, $100 \mu \mathrm{l}$ tissue extract was mixed with $100 \mathrm{mM}$ potassium phosphate buffer ( $\mathrm{pH}$ 7.0) and $6 \% \mathrm{H}_{2} \mathrm{O}_{2}$. The reaction mixture was observed at $240 \mathrm{~nm}$ (extinction coefficient of $0.036 \mathrm{mM}^{-1} \mathrm{~cm}^{-1}$ ) at intervals of $30 \mathrm{~s}$ up to $1 \mathrm{~min}$ using a UV-Vis spectrophotometer (Genesys $^{\mathrm{TM}}$ 10S UV-Vis, Thermo Scientific ${ }^{\mathrm{TM}}$, Waltham, Massachusetts, USA). To determine superoxide dismutase (SOD) activity, $100 \mu \mathrm{l}$ tissue extract was mixed with $50 \mathrm{mM}$ sodium carbonate buffer ( $\mathrm{pH} 9.8), 0.1 \mathrm{mM}$ EDTA, and $0.6 \mathrm{mM}$ epinephrine (the last component added). Afterwards, the adrenochrome formation in the next 4 min was measured using a spectrophotometer (Genesys $^{\mathrm{TM}}$ 10S UV-Vis, Thermo Scientific ${ }^{\mathrm{TM}}$, Waltham, Massachusetts, USA) at $475 \mathrm{~nm}$. For ascorbate peroxidase (APX) activity, the reaction mixture was made up of $0.1 \mathrm{mM}$ EDTA, $50 \mathrm{mM}$ potassium phosphate buffer ( $\mathrm{pH} 7.0$ ), $0.1 \mathrm{mM} \mathrm{H}_{2} \mathrm{O}_{2}, 0.5 \mathrm{mM}$ ascorbic acid, and $0.1 \mathrm{ml}$ of tissue extract. The absorption of APX was recorded at $290 \mathrm{~nm}$ using a UV-Vis spectrophotometer (Genesys $^{\mathrm{TM}}$ 10S UV-Vis, Thermo Scientific ${ }^{\mathrm{TM}}$, Waltham, Massachusetts, USA) with an extinction coefficient of $2.8 \mathrm{mM}^{-1} \mathrm{~cm}^{-1}$. Further, for determining glutathione reductase (GR) activity, $100 \mu \mathrm{l}$ of tissue extract was added with $0.2 \mathrm{mM}$ phosphate buffer ( $\mathrm{pH} 7.0), 1 \mathrm{mM}$ EDTA, $0.75 \mathrm{ml} \mathrm{dH_{2 }} \mathrm{O}$ water, $0.1 \mathrm{ml}$ of $20 \mathrm{mM}$ oxidized glutathione (GSSG) and $0.1 \mathrm{ml}$ of $2 \mathrm{mM} \mathrm{NADPH}$. The GR activity was monitored at $240 \mathrm{~nm}$ using a spectrophotometer (Genesys ${ }^{\mathrm{TM}}$ 10S UV-Vis, Thermo Scientific ${ }^{\mathrm{TM}}$, Waltham, Massachusetts, USA) with an extinction coefficient of $6.12 \mathrm{mM}^{-1} \mathrm{~cm}^{-1}$ [27].

\section{Hydrogen peroxide $\left(\mathrm{H}_{2} \mathrm{O}_{2}\right)$ and nitric oxide $(\mathrm{NO})$ analysis}

For $\mathrm{H}_{2} \mathrm{O}_{2}$ activity, after washing, the root and shoot were crushed in $1 \mathrm{ml}$ of $0.1 \%$ trichloroacetic acid (TCA) by mortar and pestle [28]. The mixture was centrifuged at 10,000 rpm for $15 \mathrm{~min}$ and the supernatant was transferred to a fresh centrifuge tube. Then, the supernatant was mixed with phosphate buffer $(10 \mathrm{mM}$, $\mathrm{pH} 7.0)$, potassium iodide (1 M), and kept in the dark for $1 \mathrm{~h}$. The optical density of the reaction mixture was recorded at $390 \mathrm{~nm}$ using a spectrophotometer (Genesys $^{\text {TM }}$ 10S UV-Vis, Thermo Scientific ${ }^{\mathrm{TM}}$, Waltham, Massachusetts, USA).

Nitric oxide (NO) activity was determined in root and shoot of maize plant based on the hemoglobin absorbance as a result of its change from oxyhemoglobin $\left(\mathrm{HbO}_{2}\right)$ to methemoglobin in presence of NO [1]. The root and shoot samples were ground and homogenized with a mortar and pestle in $1 \mathrm{ml}$ of cold buffer, which contained $0.1 \mathrm{M}$ sodium acetate, $1 \mathrm{M} \mathrm{NaCl}$, and $1 \%$ $(\mathrm{W} / \mathrm{V})$ ascorbic acid ( $\mathrm{pH}$ 6.0). The sample sap was centrifuged at $10,000 \mathrm{rpm}$ at $4{ }^{\circ} \mathrm{C}$ for $5 \mathrm{~min}$ and the supernatant was transferred to a new centrifuge tube. Subsequently, the $\mathrm{HbO}_{2}$ solution stock $(5 \mathrm{mM})$ was mixed with samples and incubated at room temperature for $5 \mathrm{~min}$. Finally, optical density was monitored at $401 \mathrm{~nm}$ using a spectrophotometer (Genesys ${ }^{\mathrm{TM}}$ 10S UV-Vis, Thermo Scientific ${ }^{\mathrm{TM}}$, Waltham, Massachusetts, USA).

\section{Determination of total soluble protein and sugar}

Total soluble protein concentration in the roots and shoots of maize plants germinated from control and treated seeds were determined using a spectrophotometer (Genesys ${ }^{\mathrm{TM}} 10 \mathrm{~S}$ UV-Vis, Thermo Scientific ${ }^{\mathrm{TM}}$, Waltham, Massachusetts, USA) [29]. Firstly, fresh samples were ground with a mortar and pestle, which contained ice-cold $50 \mathrm{mM}$ Tris-HCl, $2 \mathrm{mM}$ EDTA, and $0.04 \%(\mathrm{v} / \mathrm{v}), 2$-mercaptoethanol. Then, centrifugation was done at $12,000 \mathrm{rpm}$ for $10 \mathrm{~min}$ at $25{ }^{\circ} \mathrm{C}$, and purified supernatant was mixed with $1 \mathrm{ml}$ Coomassie brilliant blue. Finally, optical density was recorded at $595 \mathrm{~nm}$ and the standard curve was prepared with bovine serum albumin (BSA).

Grain protein concentration was carried out by the Bradford protein assay protocol [30] with some modifications. The standard curve was prepared using the BSA solution. Firstly, the sample (0.03 gm) was weighed, ground and diluted, with $10 \mathrm{ml}$ of deionized water. The resultant sap was centrifuged twice at $4000 \mathrm{rpm}$ for $10 \mathrm{~min}$ and the supernatant was transferred into a fresh 
tube. $3.0 \mathrm{ml}$ of Bradford reagent was mixed with each sample and placed at room temperature for $45 \mathrm{~min}$. After vortexing and incubation, samples were transferred to cuvettes and optical density was recorded at $595 \mathrm{~nm}$ using a spectrophotometer (Genesys ${ }^{\mathrm{TM}}$ 10S UV-Vis, Thermo Scientific ${ }^{\mathrm{TM}}$, Waltham, Massachusetts, USA).

Total soluble sugar concentration was carried out according to the protocol described earlier [1] with slight modifications. Fresh root and shoot were homogenized with a mortar and pestle in $80 \%$ ethanol. The centrifugation was homogenized at $8000 \mathrm{rpm}$ for $10 \mathrm{~min}$ and the clear supernatant was transferred to a separate microcentrifuge tube. Subsequently, $0.2 \%$ of anthrone reagent was added and incubated at $100^{\circ} \mathrm{C}$ for 8 min before placing it on ice. Finally, the optical density was monitored at $620 \mathrm{~nm}$.

\section{Analysis of $\mathrm{Fe}, \mathrm{Zn}$, and $\mathrm{Mn}$ in flour and shoot of maize plants}

The trace-elemental analysis was carried out according to the protocol described earlier [1] with minor modifications. Firstly, the freshly plucked shoots were washed in $\mathrm{CaSO}_{4}(1 \mathrm{mM})$ for $3 \mathrm{~min}$. After washing, the tissue samples were kept at $60^{\circ} \mathrm{C}$ for 3 days in an oven for drying. A mixture of $5 \mathrm{ml} \mathrm{HNO}$ and $2 \mathrm{ml} \mathrm{H}_{2} \mathrm{O}_{2}$ was used to digest the tissue samples in a glass beaker, and a microwave oven was used for heating. Flame atomic absorption spectroscopy (AAS) connects to an ASC-6100 auto-sampler air-acetylene at the atomization gas mixture system (model No. AA-6800, Shimadzu) was used to determine the $\mathrm{Fe}, \mathrm{Zn}$, and $\mathrm{Mn}$ concentration. A standard known solution was prepared and analysis was carried out [31].

\section{A thousand seeds mass (TSM)}

A thousand seeds mass is a crucial parameter for measuring the yield of maize. A thousand seeds were counted, and their average weight was measured with the help of a electronic balance (Vibra HT224R, Shinko Denshi Co. Ltd., Tokyo, Japan) [32].

\section{Determination of moisture content}

The moisture content was performed according to AOAC 2000 (Association of Official Agricultural Chemists) method [33]. Three grams of corn flour was spread uniformly on the aluminum foil and weighed using an electronic balance. Aluminum foils $(10 \mathrm{~cm} \times 10 \mathrm{~cm})$ and the weighed samples were dried in an oven at $105{ }^{\circ} \mathrm{C}$ for $3 \mathrm{~h}$. After drying, the foils were then cooled in desiccators and weight was taken. Finally, the flour sample weighed earlier was taken on the dried aluminum foil was weighed. Moisture content of the flour was determined using the following formula:

$$
\text { Moisture content }(\%)=\left(W_{1}-W_{2} / W_{1}\right) \times 100 \text {. }
$$

Here, $W_{1}=$ initial weight of the sample before drying, $W_{2}=$ final weight of the sample after drying.

\section{Determination of fat content}

Fat content was determined according to AOAC, 2000 protocol [33] with minor modifications. The bottles with lids were placed in an incubator at $105^{\circ} \mathrm{C}$ for $6 \mathrm{~h}$ to remove any moisture and to ensure the stable weight of the bottles. Six grams of the sample was weighed using an electronic balance and placed into the extraction thimble and thimble was connected to Soxhlet. $250 \mathrm{ml}$ of $\mathrm{n}$-hexane was poured into the thimble and placed on the heating mantle. The samples were heated for $3 \mathrm{~h}$ and the solvent was evaporated using vacuum condenser. Subsequently, the bottles were incubated at $80-90{ }^{\circ} \mathrm{C}$ for $1 \mathrm{~h}$, cooled in a desiccator, and reweighed. The following formula was used to calculate the fat content:

Fat content $(\%)=($ weight of fat/weight of sample $) \times 100$.

\section{Estimation of crude fiber}

The crude fiber content in flour was carried out by the AOAC, 2000 method [33]. Briefly, samples (3 g) were weighed and dried in an oven. $250 \mathrm{ml}$ of hot $\mathrm{H}_{2} \mathrm{SO}_{4}$ $(0.125 \mathrm{M})$ along with samples were poured into a $600 \mathrm{ml}$ beaker of the condenser and boiled for $30 \mathrm{~min}$. The samples were then filtered and washed with boiling water and transferred the residue back to a beaker. Again, $250 \mathrm{ml}$ of $\mathrm{NaOH}(0.313 \mathrm{M})$ was added in a beaker in the condenser and boiled for $30 \mathrm{~min}$. Subsequently, the samples were filtered and washed stepby-step with boiling water, $1 \% \mathrm{HCl}$, boiling water, and then finally washed twice with ethanol. Afterword, the samples were kept overnight at $100{ }^{\circ} \mathrm{C}$ and cooled in a desiccator. The samples were placed into the moisture free crucible, weighed, and burnt for $3 \mathrm{~h}$ at $600{ }^{\circ} \mathrm{C}$ in a muffle furnace, again cooled in a desiccator, and final weight was taken. Following formula was used to calculate the crude fiber content:

$$
\text { Crude fiber content }(\%)=\left(W_{2}-W_{1}\right) / W_{0} \times 100,
$$

where $W_{1}=$ weight of crucible before sample ashing, $W_{2}=$ weight of crucible after sample ashing, and $W_{0}=$ weight of the sample. 


\section{Determination of ash content}

Ash content was determined by the AOAC, 2000 procedure [33]. An empty crucible with lids was placed in the furnace at $600{ }^{\circ} \mathrm{C}$ overnight and cooled in a desiccator for $30 \mathrm{~min}$, and then weight was taken by an electronic balance. $6 \mathrm{~g}$ sample was weighed and taken into the crucible, and burned in a muffle furnace at $600{ }^{\circ} \mathrm{C}$ for $6 \mathrm{~h}$. Afterword, the crucibles were cooled in desiccators, and the final weight was taken with the lid. The following formula was used to calculate the ash content:

$$
\begin{aligned}
\text { Ash content }(\%)= & (\text { weight of ash/weight of sample }) \\
& \times 100 .
\end{aligned}
$$

\section{Statistical analysis}

All the field studies were performed with three independent replications for each experimental sample on the basis of complete randomized block design (CRBD). The significance level was tested at $p<0.05$ by oneway ANOVA followed by Duncan's multiple range test (DMRT) in SPSS statistic 20 software. All graphical figures were prepared using GraphPad prism 6 versions.

All the biochemical analysis and assays have been randomly selected from individual plant species having at least three replications. Every experiment was repeated three times to ensure the reproducibility of the data. Fresh weight was taken initially and converted to per gram during data analysis.

\section{Results}

\section{Changes in seeds surface}

The seed surface showed significant changes due to the influence of LFGD Ar + air plasma treatment compared with control, respectively (Fig. 2a-c). Further,
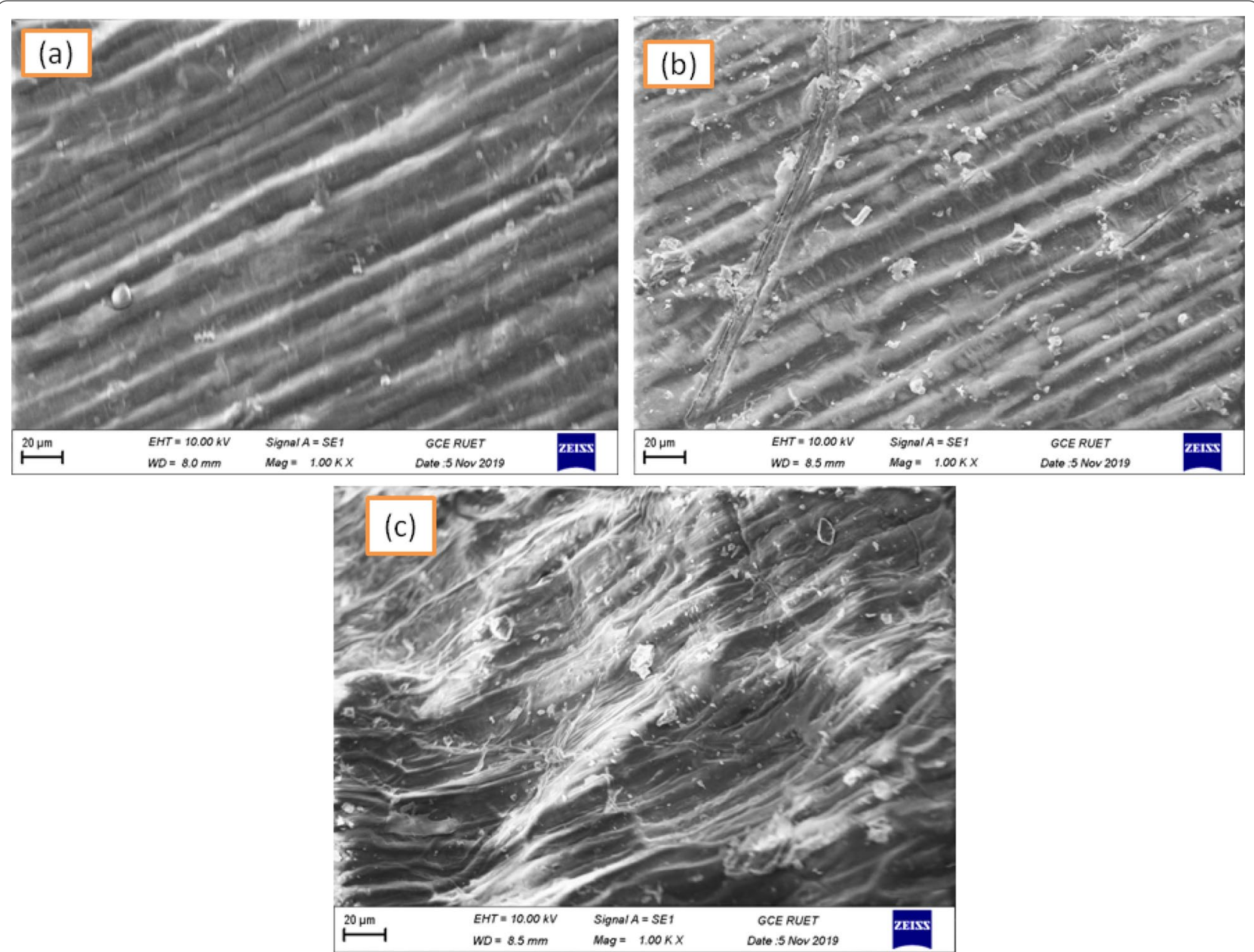

Fig. 2 SEM images of maize-treated seeds with non-treated seeds surface: a control, b 90 s, c 120 s LFGD Ar + air plasma treatment. The scale bar is $20 \mu \mathrm{m}$ 
we observed that the seed coat becomes fractured and chapped due to plasma treatment (Fig. 2b, c).

\section{Seeds germination}

The positive response of LFGD plasma was observed on the seed germination with different treatment times. The seed germination rate significantly increased among the plasma-treated seeds compared to the control. The highest germination rate was shown in 90-s treatment duration with a value of $85.55 \%$ increase as compared control seeds (Fig. 3a).

\section{Morphological features and chlorophyll score}

Ar + air plasma treatment showed significant changes in maize seedling growth compared to control. In this study, the morphological parameters showed substantial differences in maize plants grown from the $\mathrm{Ar}+$ air-treated seeds compared to non-treated controls (Fig. 3b-g). Besides, total chlorophyll scores significantly increased in maize plants generated from the treated seeds compared with control (Fig. 3h).

\section{The activity of antioxidant enzymes (APX, SOD, CAT, and GR) in seedlings}

In plants, APX and SOD activity significantly increased in both shoots and roots of plants grown from the $\mathrm{Ar}+$ air plasma-treated seeds compared to non-treated control seed (Fig. 4a-d). In addition, interestingly, CAT and GR activities showed no significant changes in both shoot and root of plants generated from the seeds treated compared with control (Fig. 4e-h).

\section{Analysis of hydrogen peroxide $\left(\mathrm{H}_{2} \mathrm{O}_{2}\right)$ and nitric oxide (NO)} We determined the concentration of hydrogen peroxide $\left(\mathrm{H}_{2} \mathrm{O}_{2}\right)$ and nitric oxide $(\mathrm{NO})$ in both shoots and roots of maize plants germinated from the plasma-treated seeds. We observed that the $\mathrm{H}_{2} \mathrm{O}_{2}$ concentration showed a significant increase in both shoot and root of plants compared with controls (Fig. 5a, b). NO concentration showed no significant change in the shoot or root, in response to plasma treatment (Fig. $5 \mathrm{c}, \mathrm{d}$ ).

\section{Biochemical features}

Maize plants germinated from $\mathrm{Ar}+$ air-treated seeds showed a significant increase in total soluble protein in shoot and root compared to control (Fig. 5e, f). In addition, the total soluble sugar concentration also significantly increased in the shoot and root of maize plants generated from the plasma-treated seeds compared to the control (Fig. 5g, h).

\section{Determination of trace elements ( $F e, ~ Z n$, and $\mathrm{Mn}$ ) in grain and shoot}

Atomic absorption spectroscopy (AAS) analysis showed that the Fe concentration significantly increased in both grain and shoot of the plants germinated from the plasma treatment compared with controls (Fig. 6a, b). In contrast, $\mathrm{Zn}$ concentration showed no increase in both grain and shoot of the plants germinated from the plasmatreated seeds compared with control (Fig. 6c, d). Also, Mn concentration showed a significant increase in the grain of plants originated from the treated seeds compared to non-treated controls (Fig. 6e).

\section{Determination of protein in grain}

Protein concentration showed considerable changes due to LFGD plasma treatment in the grain of maize plants compared to the control. The highest protein concentration was shown in the plants generated from seeds treated for $120 \mathrm{~s}$ (Fig. 6f).

\section{A thousand seeds mass (TSM)}

Thousand seeds mass is a vital factor which indicates the productivity of maize plants in different regions. TSM significantly increased in maize plants generated from the treated seeds compared with controls. The highest thousand seed mass was found in response to $120 \mathrm{~s}$ treatment time, with a value of $272.33 \mathrm{~g}$ (Fig. 7a).

\section{Moisture content}

The moisture content was measured to determine the water absorption in maize grain, which is essential for productivity. The high moisture content was shown in control with a value of $12.20 \%$, and the lowest moisture content was found in the 90-s treatment time with a value of $6.6 \%$, respectively (Fig. $7 \mathrm{~b}$ ).

\section{Fat content}

The fat content showed a greater increase in maize grain, which was grown from the plasma-treated seeds compared with the non-treated control, and the highest fat

(See figure on next page.)

Fig. 3 Changes in seed germination rate and morphological parameters in wheat plants in effect of plasma treatment for different duration a germination, $\mathbf{b}$ shoot length, $\mathbf{c}$ root length, $\mathbf{d}$ fresh weight, e dry weight, $\mathbf{f}$ plant height, $\mathbf{g}$ stem diameter, $\mathbf{h}$ chlorophyll score in maize plants generated from Ar + air plasma-treated seeds. Individual data were expressed as the mean \pm standard deviation of treatments ( $n=3$ ). Different letters specify the significant changes in each column, as determined by the Duncan test $(p=0.05)$ 
(a)

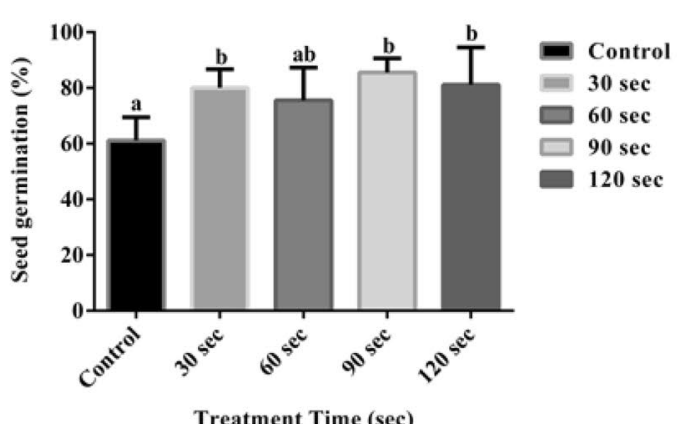

(c)

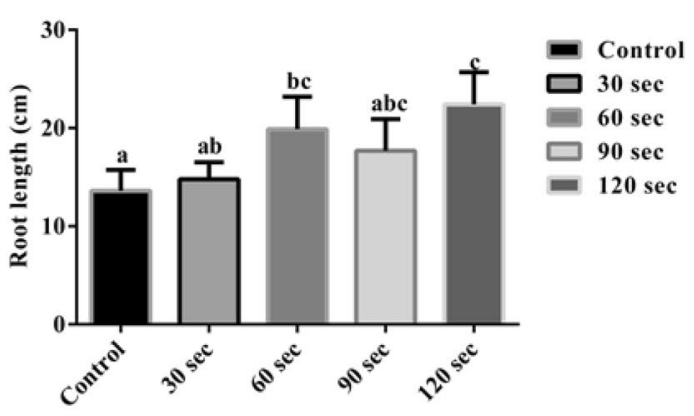

Treatment Time (sec)

(e)

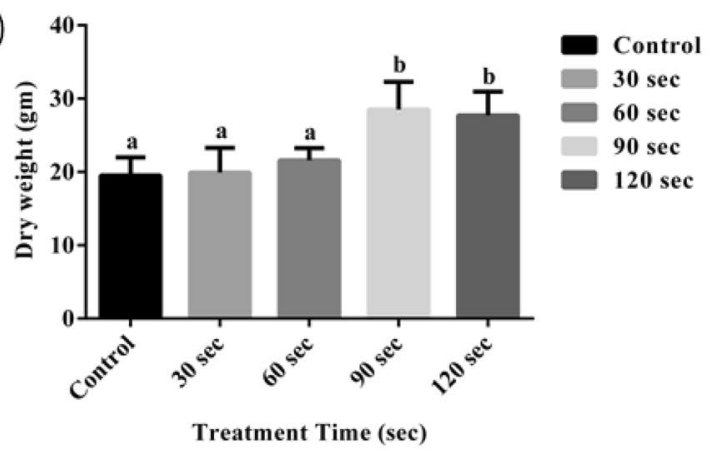

(g)

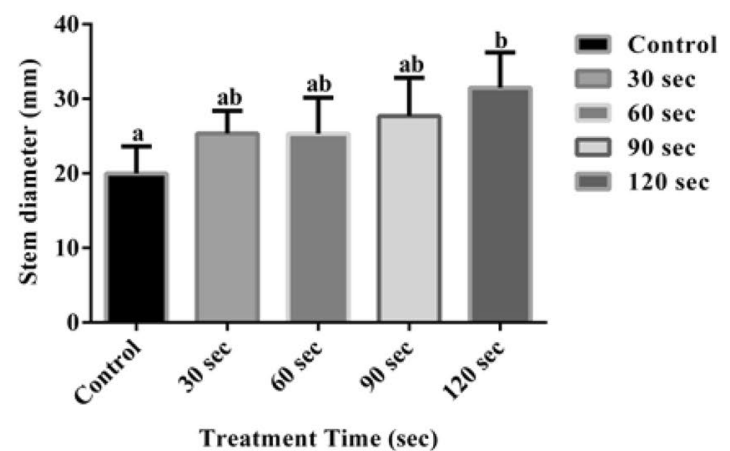

(b)

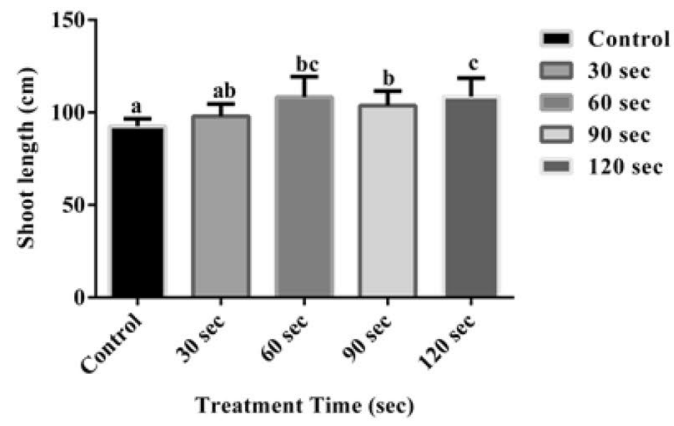

(d)

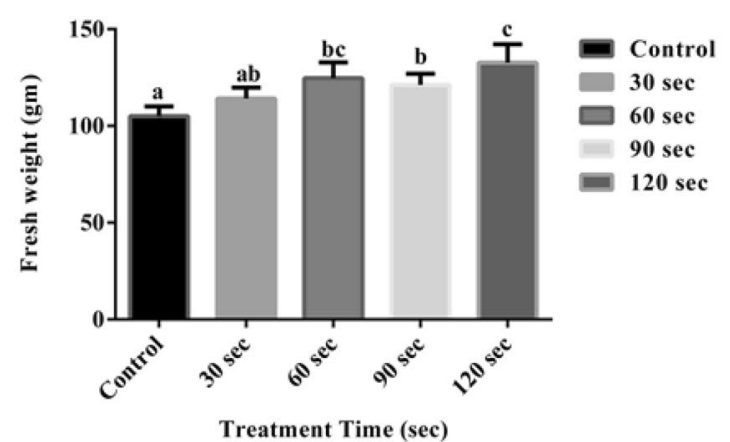

(f)

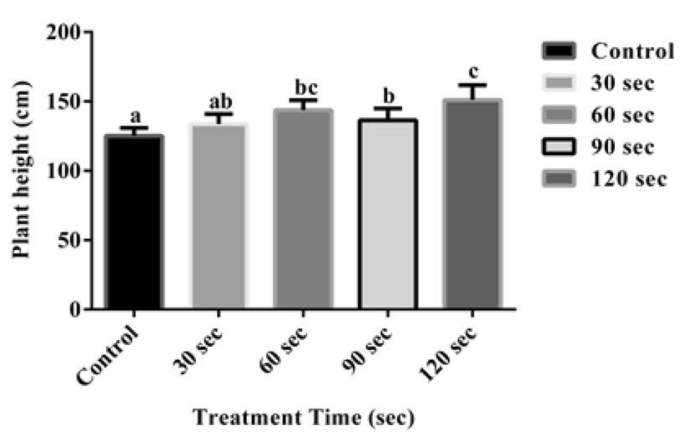

(h)

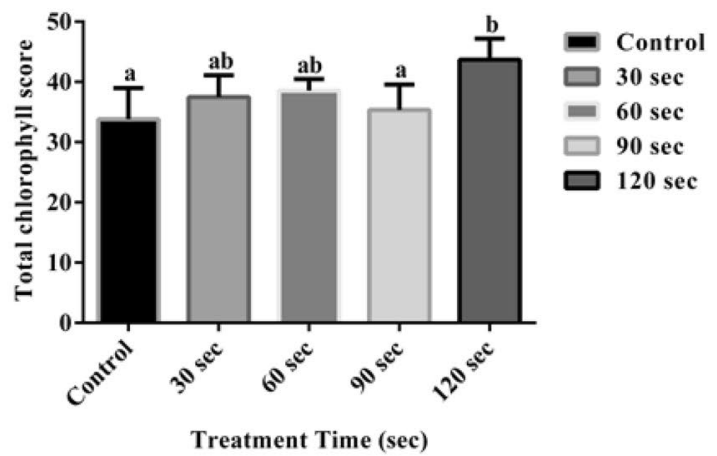

Fig. 3 (See legend on previous page.) 
content was monitored in those with 90-s treatment. Fat content ranged from 4.96 to $9.76 \%$, as shown in Fig. 7c.

\section{Crude fiber content}

When compared to the control, crude fiber content increased significantly as a result of plasma treatment. Fiber content ranged from 1.10 to $2.13 \%$, as shown in Fig. 7d.

\section{Ash content}

Ash produces oxides of inorganic elements, which useful for metal analysis. Ash content notably improved in maize grain germinated from the treated seeds compared to controls. The highest ash content was shown in the 90 -s treatment time with a value of $2.96 \%$, and the lowest ash content was found in control with a value of $1.42 \%$, respectively (Fig. 7e).

\section{Discussion}

Recently, plasma technology has drawn much attention to researchers for the enhancement of seed performance, traits, and yields in essential crop plants. It is pointed out that the LFGD plasma can be a good choice for the improvement of germination and growth in maize plants. Plasma technology produces harmless UV radiation, free radicals, and reactions of chemicals that play a vital role in the dormancy flouting [34].

Initially, LFGD plasma treatment caused changes in the seed coat configuration and functionalities. The changes in seed configuration may be related to water permeability. The thin seed surface and the roughness of the seed exterior are responsible for quicker water absorption and nitrogenous compound [35]. It has been shown that nitrogen is absorbed into the seed coat, which promotes germination, which is in line with our findings [1]. Protein and starch granules are randomly distributed on the seed surface, which contains asymmetrical shapes and dissimilar sizes and also improves the seed germination [1]. In the present study, the seed surface showed different sizes and irregular shapes due to LFGD plasma treatment, as well as a significant improvement in seed germination in treated seeds was observed. In the absence of water, nitrate and phosphorus molecules can help maize plants grow faster [5].

In addition, exposure of maize seeds to the LFGD $\mathrm{Ar}+$ Air plasma treatment showed stimulating effects on germination rates and seedling growth. In our experiment, the exposure of the most significant treatment (90 and $120 \mathrm{~s}$ ) of LFGD plasma may be directly or indirectly involved in accelerating enzymatic activities related to seed germination as well as the inner decomposition of essential nutrients, causing those compounds to increase the utilization of seed reserves and seedling growth. A number of studies have reported that plasma treatments, including cold plasma and atmospheric pressure plasma, significantly increase seed germination $[2,36]$. Further, results showed that germination rate is significantly increased in the plasma-treated wheat [37]. Moreover, several studies also proved the enhancement of the growth and development of plants originated from the plasma treatment $[17,36,38]$. The seedling growth of the wheat was significantly improved by cold plasma treatment [34]. Cold plasma inductions were shown to improve seed germination, seeding growth, antioxidants, drought stress tolerance potentiality, and tomato defense gene expression [39]. Also, previous research has shown that cold plasma improves the germination and growth of soybean see [2], oilseed rape [8], hemp [26], and other agronomically and economically important crops. Zhou et al. reported that the seedling growth of tomato was increased considerably using atmospheric pressure plasma treatment [36]. The capacity of DBD (dielectric barrier discharge) plasma treatment to improve seed germination rate and vigor index in wheat plants was also investigated [40, 41]. Furthermore, when radish sprout lengths were exposed to oxygen RF plasma, they increased by $60 \%$ [42]. The recent investigation showed that the LFGD plasma treatment substantially increased growth parameters, including shoot length, root length, fresh weight, dry weight, plant height, and stem diameter compared to control. Our outcome indicates that the enhancement of the maize seedlings pre-treated with LFGD plasma was partially due to their growth. In addition, chlorophyll score is greatly increased in LFGD plasma-treated seeds that lead to higher photosynthesis of plants, which is in agreement with the previous studies [43].

Plasma treatment has improved cell and enzyme activity, and it plays a magnification function in the advanced process of germination [9]. The antioxidant enzymes are a part of the defense system associated with $\mathrm{H}_{2} \mathrm{O}_{2}$ scavenging and is strongly correlated with the capability of

(See figure on next page.)

Fig. 4 Changes in enzymatic activities in maize plants subjected to plasma treatment. APX performance in a shoot and $\mathbf{b}$ root, SOD performance in c shoot and $\mathbf{d}$ root, CAT performance in e shoot and $\mathbf{f}$ root, GR performance in $\mathbf{g}$ shoot and $\mathbf{h}$ root of maize plants generated from the Ar + air treatment. Different letters indicate a significant difference within a mean \pm standard deviation of treatments $(n=3)$ as determined by the Duncan test $(p=0.05)$ 
(a)

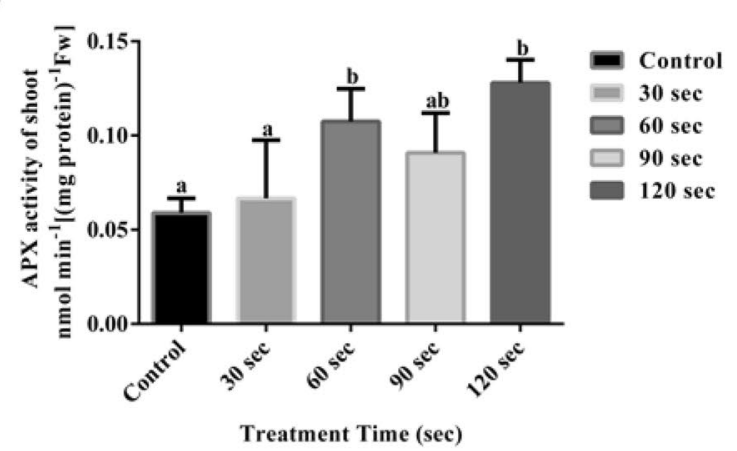

(c)

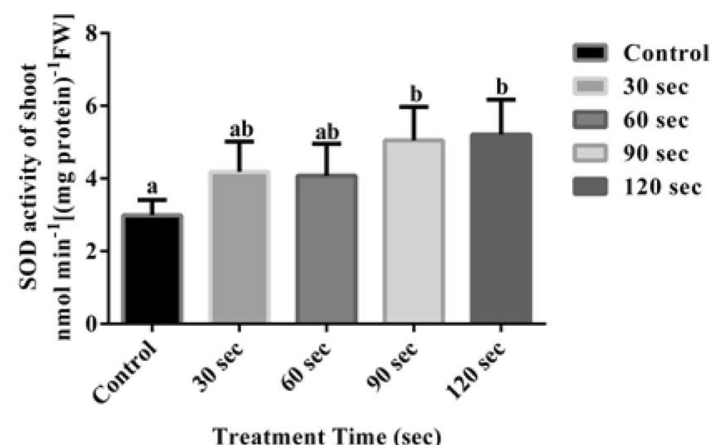

(e)

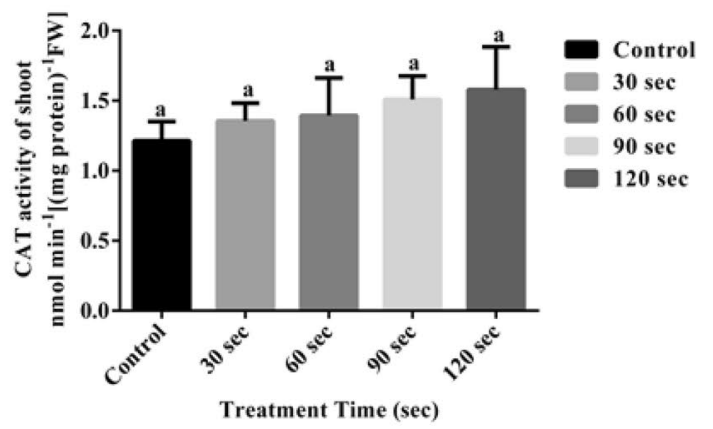

(g)

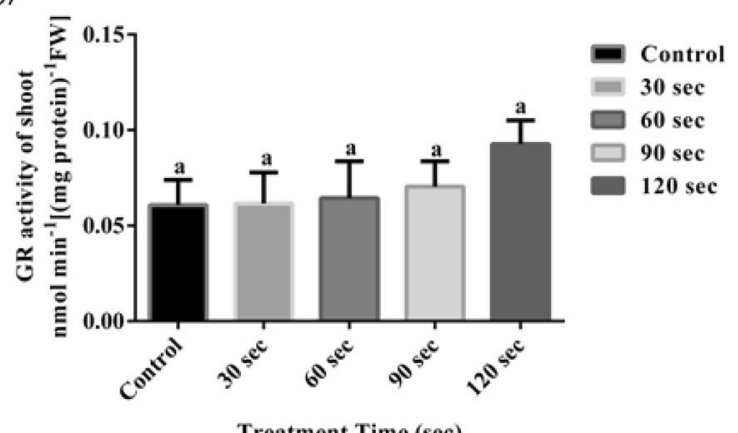

(b)

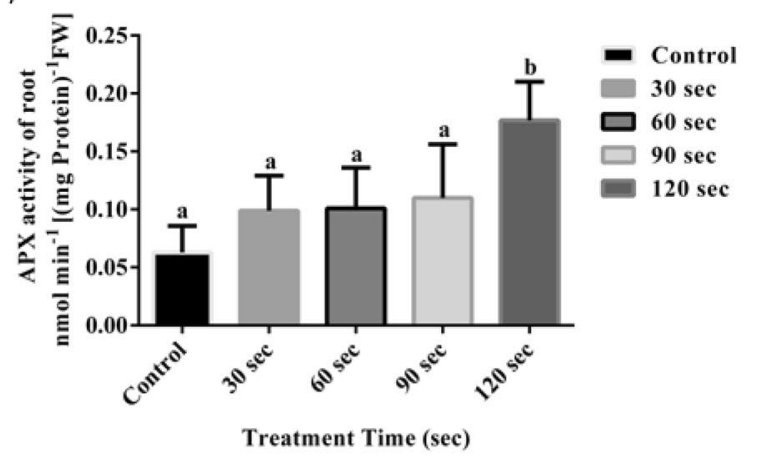

(d)

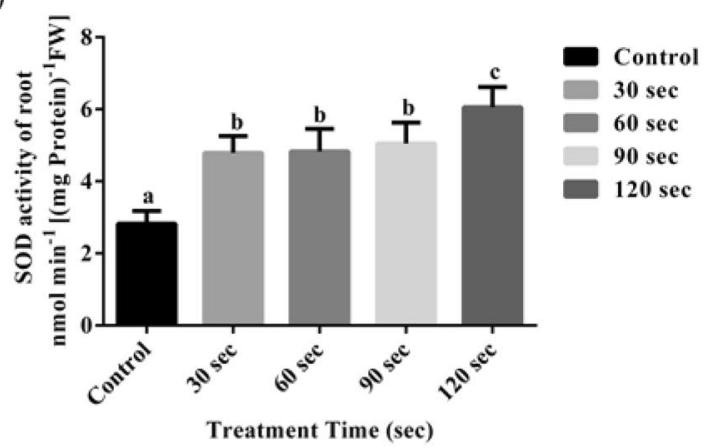

(f)

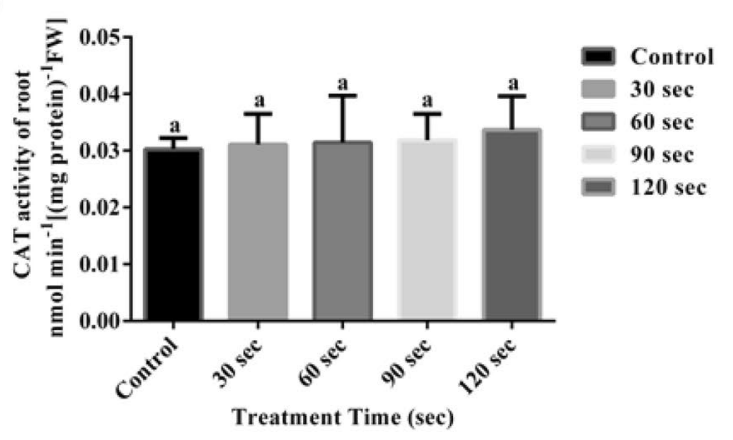

(h)

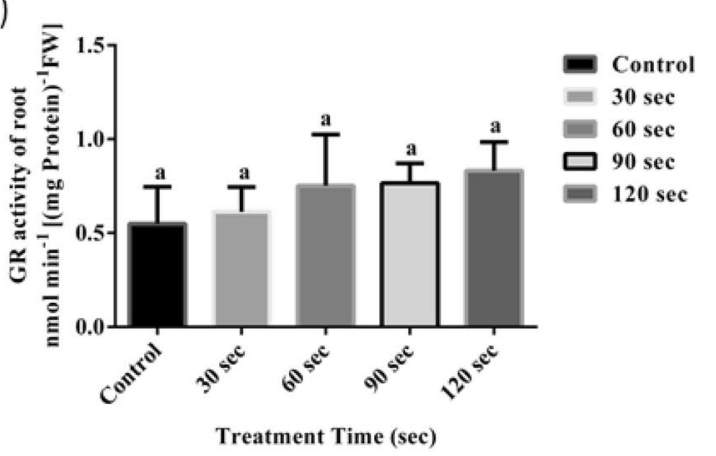


plant's stress tolerance. The low activity of the antioxidant enzyme may lead to the accumulation of $\mathrm{H}_{2} \mathrm{O}_{2}$ in plant cells [1], which causes the reduction of crop production. Antioxidant enzymes are used as scavenger and reduce the harmful effects and detoxification of ROS, including catalase (CAT), superoxide dismutase (SOD), ascorbate peroxidase (APX), and glutathione reductase (GR) enzymes. The antioxidant can act as a substrate for the enzyme, which mainly works actively against oxygen scavenging. The previous study reported that the plasma treatment increased the antioxidant enzyme activities, including SOD, and POD in tomato seedlings [16] and in maize [19]. The superoxide dismutase activity in maize was greatly increased by the plasma-treated seeds [6]. In our study, enzymatic data revealed that antioxidant enzymes APX and SOD were significantly increased in both the shoot and root of maize plants due to LFGD plasma treatment. This result implicates that the LFGD plasma treatment plays a crucial role in condensing the oxidative injure and assisting to sustain standard physiological metabolic actions, leading to improved maize seedling growth.

Interestingly, CAT and GR activity showed no change in this experiment at a significance level. Both $\mathrm{H}_{2} \mathrm{O}_{2}$ and $\mathrm{NO}$ are signaling molecules, which are responsible for the production of harmful effects of the ROS and RNS. Among these, oxygen-containing functional groups in plasma species enrich the seed coat, resulting in a significant increase in wettability and, as a result, a higher seed germination rate can be observed [35, 41]. The interaction of RNS and ROS produced by plasma treatment on the maize seed coat may improve seed germination rate [5]. $\mathrm{NO}$ is an unstable compound [44] and is produced from $\mathrm{NO}_{3}{ }^{-}$by plants that might act as a signaling molecule $[45,46]$. However, only $\mathrm{H}^{+}$ions have a negative effect, especially in the early phases of plant development, including germination and growth [31]. The higher amount of $\mathrm{H}_{2} \mathrm{O}_{2}$ in plant physiology is considered as toxic [31]. It plays a vital role in the physiological process, including the development and stress of crop plants $[21,34] . \mathrm{H}_{2} \mathrm{O}_{2}$ is directly related to the seed germination rate and growth of plants [1]. $\mathrm{H}_{2} \mathrm{O}_{2}$, along with ROS, is considered to be the principal cause of seed inferiority and failure of seed viability [47]. Other researchers have found that the $\mathrm{H}_{2} \mathrm{O}_{2}$ concentration increased in the shoot and root of wheat plants derived from $\mathrm{Ar} / \mathrm{O}_{2}$ plasma-treated seeds [1]. In the recent study, only $\mathrm{H}_{2} \mathrm{O}_{2}$ activity showed a considerable change in the shoot and root of maize plants. However, NO activity did not show any changes in maize plants by LFGD Ar+air plasma treatment. It was reported that the long-term plasma treatment has the contrary effect on the yield [46] and produces reactive oxygen species (ROS). The overproduction of reactive oxygen species (ROS) is responsible for cell death and tissue damage [6]. The balance amount of ROS could promote the growth and development of plants. Our study expressed that the LGFD plasma regulated the reactive oxygen species with optimum $\mathrm{H}_{2} \mathrm{O}_{2}$ levels in maize plants without triggering the $\mathrm{H}_{2} \mathrm{O}_{2}$ scavengers.

It strongly implies that the Ar+Air plasma-induced $\mathrm{H}_{2} \mathrm{O}_{2}$ is not only responsible for enhancing maize growth, but also triggers the antioxidant enzymes such as APX or CAT. APX is directly linked to the fine-tuning of $\mathrm{H}_{2} \mathrm{O}_{2}$ detoxification and is maintained by the sulfhydryl group [7]. The SOD enzyme is a kind of metalloenzyme that can to convert superoxide radicals into $\mathrm{H}_{2} \mathrm{O}_{2}$ and $\mathrm{O}_{2}$ [41]. SOD is a defense antioxidant enzyme, especially for the counteracting superoxide $\mathrm{O}_{2}^{-}$in plant. Glutathione reductase (GR) is a plant enzyme that is involved in both biotic and abiotic stress [48]. The increased quantity of GR plays a crucial role in Fe homeostasis in gramineous plants, allowing plants to deal with Fe shortage [49].

Plasma treatment improved the decay of carbohydrate and soluble protein $[6,50]$. Soluble protein and sugar are both correlated to superior stress tolerance in plants and protect the membrane and macromolecules during drought stress [36, 38]. Several studies have shown that the soluble protein and sugar content significantly increased in soybean seedlings [8] and rice seedlings [8] after plasma treatment. Yield and photosynthesis are closely related to soluble sugar content [50]. Soluble sugar plays an essential role in plant metabolism [2]. Soluble protein plays a vital role in plant growth, and it is essential for different plant enzyme activities that can reflect the plant's metabolism [2]. In the present investigation, both soluble proteins and soluble sugar content significantly increased between the shoots and roots of maize plants under LFGD plasma treatment compared with the control. The endosperm, which has a high concentration of carbohydrates and protein, is the most significant component of the maize kernel utilized in snack

(See figure on next page.)

Fig. 5 Changes in signaling molecules and biochemical activities in maize plants subjected to plasma treatment. Hydrogen peroxide $\left(\mathrm{H}_{2} \mathrm{O}_{2}\right)$ concentration in a shoot and $\mathbf{b}$ root, nitric oxide (NO) concentration in c shoot and $\mathbf{d}$ root, total soluble protein in $\mathbf{e}$ shoot and $\mathbf{f}$ root and total soluble sugar in $\mathbf{g}$ shoot and $\mathbf{h}$ root of maize plants originated from the plasma-treated seeds. Different letters specify the significant changes within a mean \pm standard deviation of treatments $(n=3)$ as determined by the Duncan test $(p=0.05)$ 
(a)

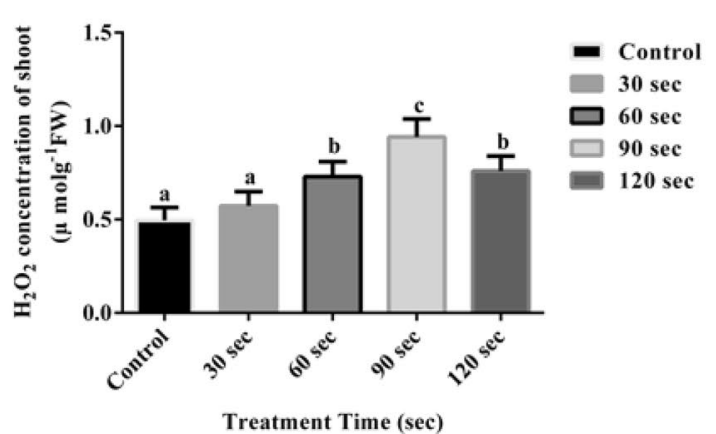

(c)

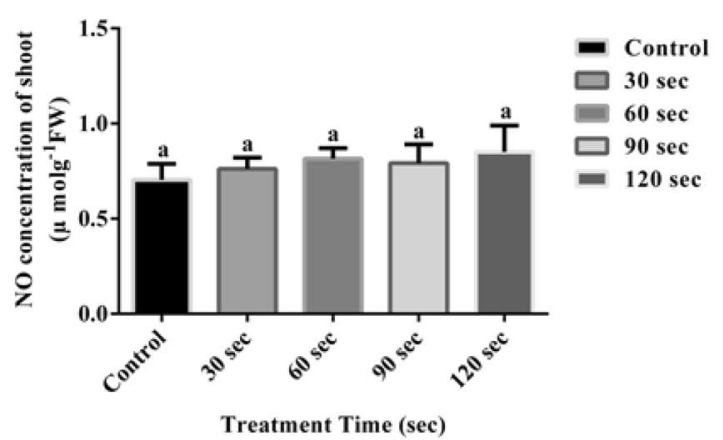

(e)

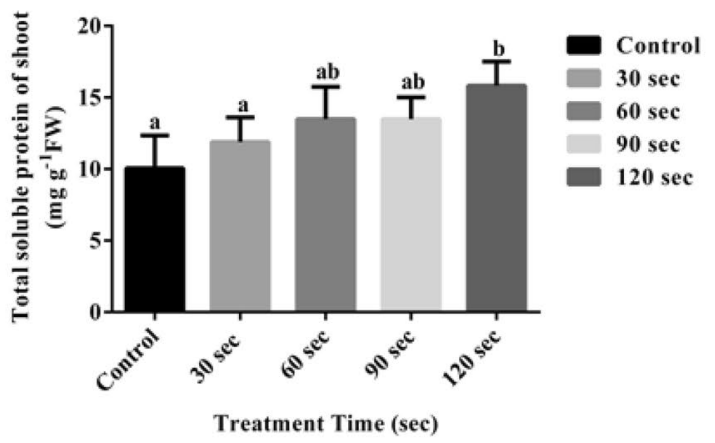

(g)

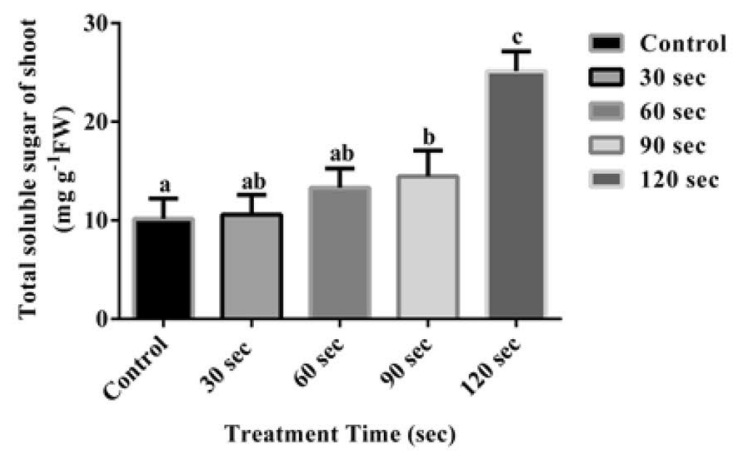

(b)

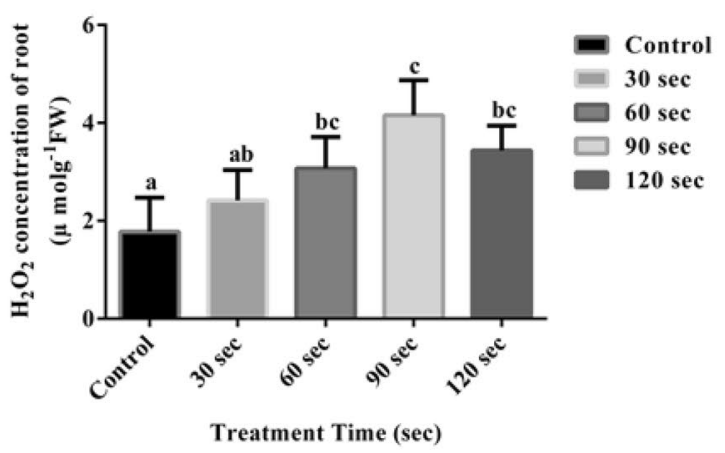

(d)

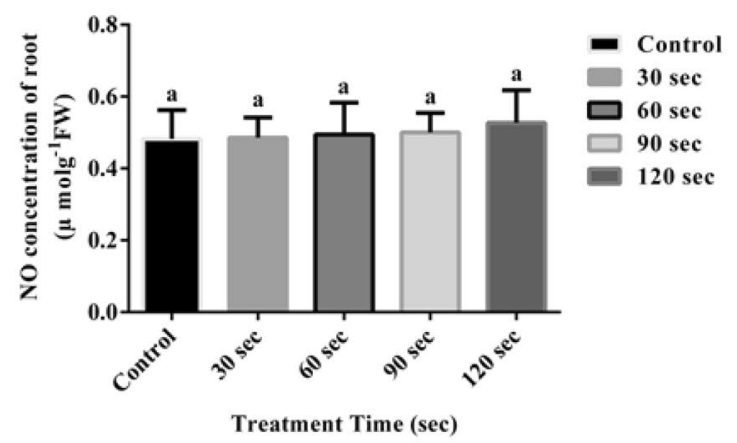

(f)

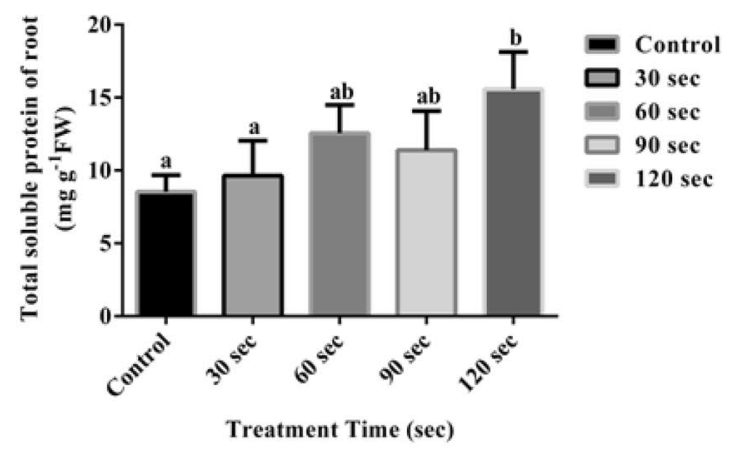

(h)

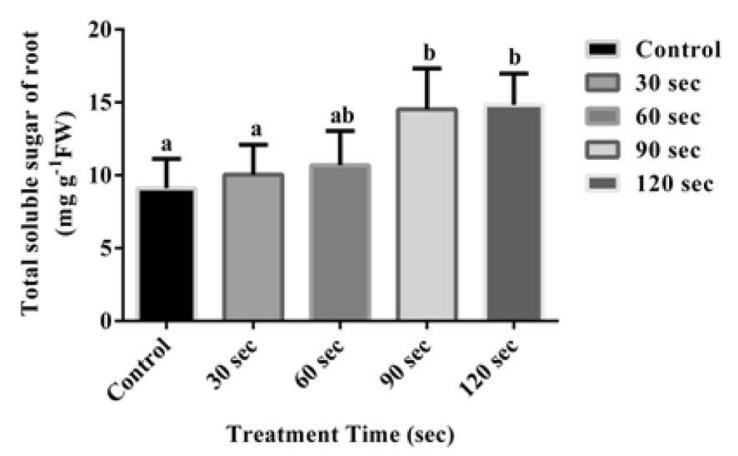

Fig. 5 (See legend on previous page.) 
(a)

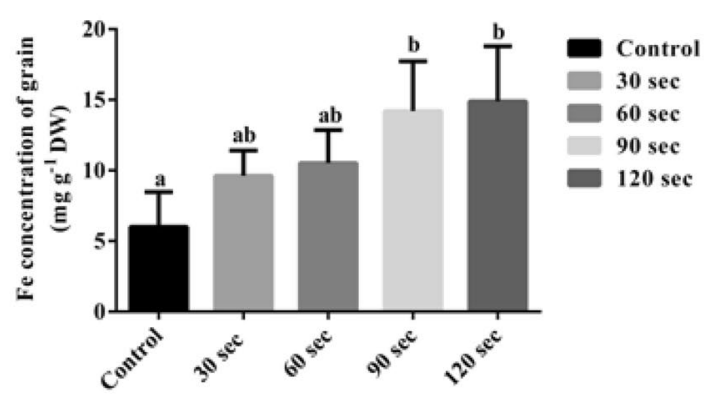

(c)

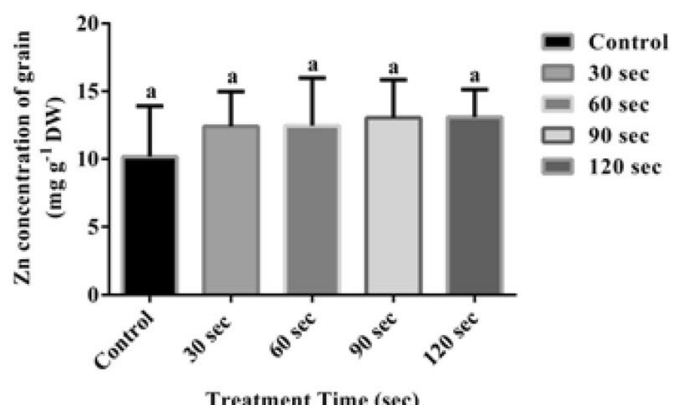

(e)

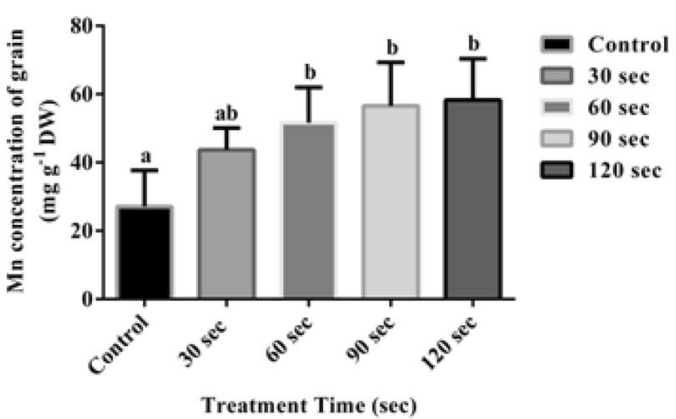

(b)

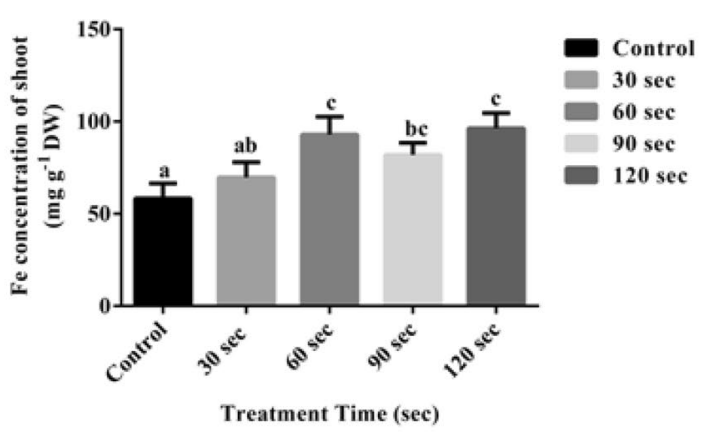

(d)

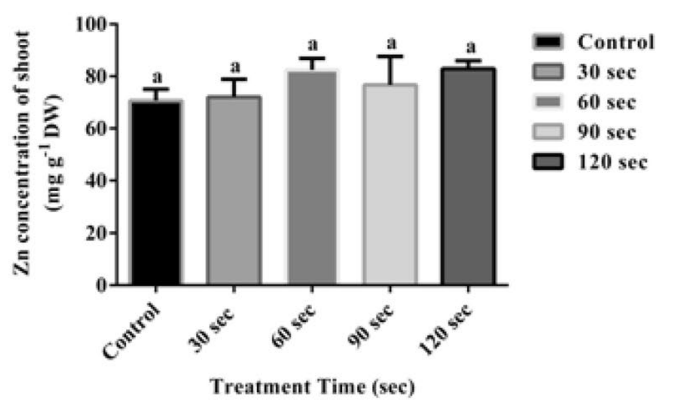

(f)

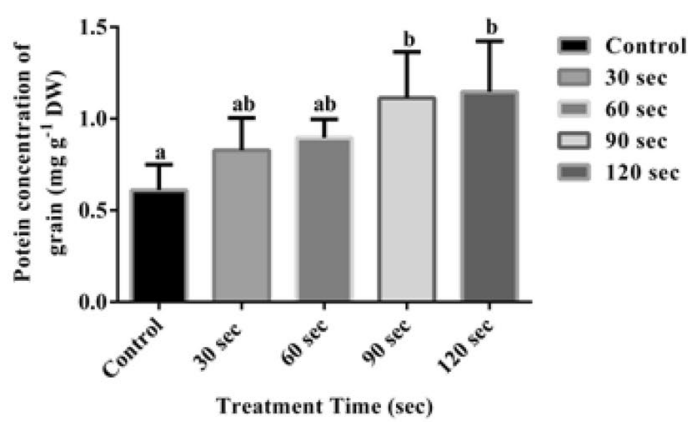

Fig. 6 Changes in trace-elements concentration, Fe concentration in a grain and $\mathbf{b}$ shoot, Zn concentration in c grain and $\mathbf{d}$ shoot, Mn concentration in $\mathbf{e}$ grain and protein concentration in $\mathbf{f}$ grain of maize plants grown from the plasma-treated seeds. Different letters specify the significant changes within mean \pm standard deviation of treatments $(n=3)$ as determined by the Duncan test $(p=0.05)$

manufacturing [51]. Increased enzyme activity such as $\alpha$ amylase and protease by plasma treatment could promote soluble sugar and protein content [38]. The LFGD plasma treatment improved the soluble protein and sugar contents, which may explain the rise of maize seedling growth.

The plasma technique is now an efficient method for enzymatic arsenic and selenium ion extraction from rice flour [52]. Trace elements are present in the living tissues in a small amount and function as catalysts in enzyme systems. It plays a vital role in human body deficiencies, which reduce the activity of the concerned enzymes. The plant's ability to convert $\mathrm{Fe}^{3+}$ to $\mathrm{Fe}^{2+}$ is required for the utilization of Fe [53]. Maize is a desirable food for Fe biofortification, dietary intake, and typical eating behaviors associated with ID and anemia [54]. In our study, Fe significantly increased in the grain and shoot of maize plants, and $\mathrm{Mn}$ also showed the same result in grain. The high levels of micronutrients $\mathrm{Zn}, \mathrm{B}$, and Mo will aid in maize seed germination, emergence, and stand establishment [55]. In contrast, $\mathrm{Zn}$ showed no significant relationship between grain and shoots of maize plants due to plasma treatment. The present study proved that plasma technology is a potential tool for maize plants, to improve the nutritional values and overcome malnutrition deficiency.

As nutrition is a major global problem in the world today, our study showed that plasma technology is a potential technique for crop improvement. Grain weight means the grain size and yield of grain with flour yield 


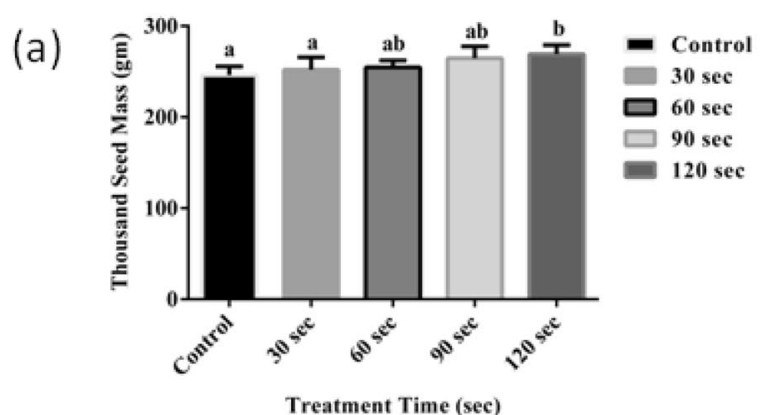

(b)

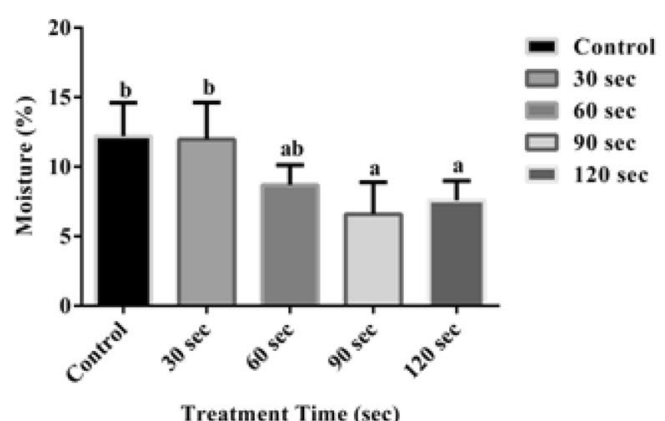

(d)

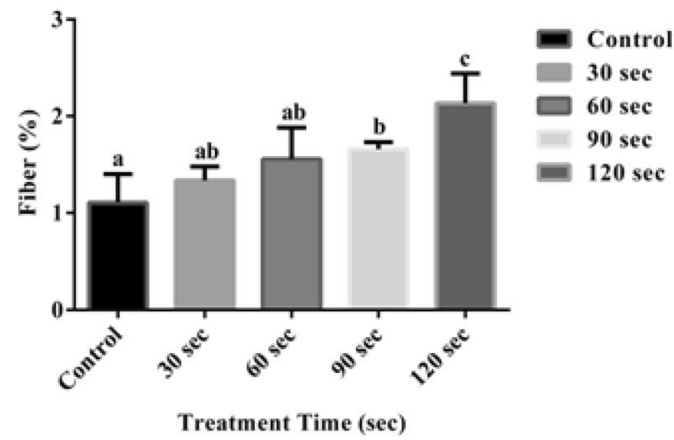

(c)

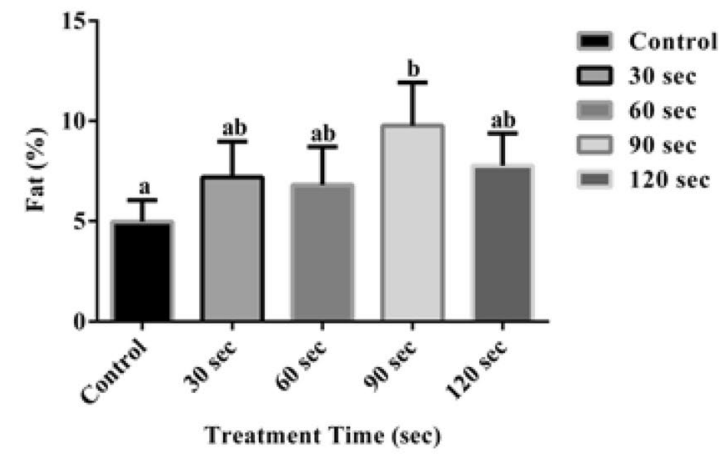

(e)

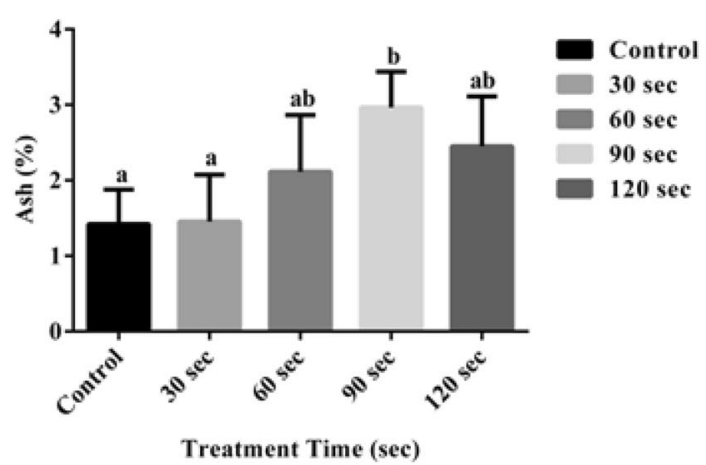

Fig. 7 Changes in nutritional status in maize plants subjected to plasma treatment. a Thousand seed mass, $\mathbf{b}$ moisture content, $\mathbf{c}$ fat content, $\mathbf{d}$ crude fiber content, and $\mathbf{e}$ ash content in grain of maize plants mature from the plasma-treated seeds. Different letters specify the significant changes within the mean \pm standard deviation of treatments $(n=3)$ as determined by the Duncan test $(p=0.05)$

[56]. The thousand-grain mass is an important parameter for determining how much productivity wheat plants exhibit in different region [56] or conditions. In the present study, a thousand grains masses greatly improved in maize plants and ranged from $246.0 \mathrm{~g}$ to $269.0 \mathrm{~g}$, respectively. Protein content showed an increase in maize grain due to plasma treatment. The moisture content is considered to determine the water absorption in wheat grains [57]. Previous results reported that the moisture content ranged from 10.31 to $13.75 \%$ in wheat $[32,58]$, maize 7.1-7.13\% [5], 4.3-6.7\% [59], oat 8.5-9.8\% [60]. The current study revealed that the moisture content showed a range from 6.6 to $12.20 \%$ in maize grain, respectively, which was not a correlated result in previous recorded. Fat is an essential source of energy, structural compounds, contains vitamins, physiological functions as for human health. The percentage of fat content in maize seed improved by 6.633 percent after $90 \mathrm{~s}$ of LFGD plasma treatment compared to $5.133 \%$ in control grain [5]. Previous research found that the fat content of oats ranged from 6.7 to $10.3 \%$ [60]. In this study, the fat content increased in the treated seeds with Ar + air plasma treatment. The fat content of grains ranged from 4.96 to $9.76 \%$ in this study, which was approximately the same as in previous reports. 
Crude fiber is a source of nutrition for human health. It plays a significant role in the digestive system because of its low amount of crude fiber. The percentage of crude fiber content was previously recorded in maize at $1.39-1.57 \%$ [5], $4.9-6.2 \%$ [59], and oat at $2.1-3.5 \%$ [60]. Crude fiber ranged from 1.10 to $2.13 \%$ in the present study, which was approximately correlated with founding in the previous record. Ash is a light color, a remainder, and the ruins of organic subjects at high temperatures in the muffle furnace. Previous studies have demonstrated that the ash content of wheat ranged from 1.06 to $2.78 \%$ [58] maize $3.94-4.75 \%$ [5], $1.0-2.0 \%$ [59], rice $0.8-2.6 \%$ [61], and oat $1.2-1.3 \%$ [60]. Our study showed that the ash content ranged from 1.19 to $2.96 \%$, respectively, in maize grain, which was correlated with the previous studies [58].

\section{Conclusion}

This study focused on seed germination, nutritional values, and growth of maize seedlings due to LFGD plasma treatment. The Ar+air gas plasma treatment increased the seed germination, antioxidant enzyme activities, nutritional properties, and seedling growth of maize plants, especially 120 -s treatment time showed best effect. So, our results suggest that LFGD plasma treatment has a positive effect on the maize plant that can be used in the future for advancement of the agronomic possibilities.

\section{Acknowledgements}

We are grateful to Department of Glass and Ceramic Engineering (GCE), Rajshahi University of Engineering \& Technology (RUET), Rajshahi-6205, Bangladesh.

\section{Authors' contributions}

MdSRS, MH, and MdAR conceptualized the whole project. MdSRS and MH performed most of the experiments and wrote the manuscript. MdFH, was actively involved in the experiment. MRT, MdMR performed seed treatment by plasma technology. KMdK-B-F, SAS contributed in methodology, software analysis. AHK contributed in biochemical analysis. MME and AME-S provided financial support and revised the manuscript. MdAR supervised the whole work. All authors read and approved the final manuscript.

\section{Funding}

The current work was funded by Taif University Researchers Supporting Project (Project number: TURSP - 2020/75), Taif University, Taif, Saudi Arabia and Research grant from the Faculty of Life Sciences, University of Bangladesh.

\section{Availability of data and materials}

The datasets generated and analyzed during the current study are available from the corresponding author on reasonable request.

\section{Declarations}

\section{Ethics approval and consent to participate}

Formal ethical approval is not necessary for this experimental work as the plant line used in this work is a cultivated genotype. In addition, the seeds were collected from the local market; hence, permission and/or licenses for collection of seed specimens are not required complying with relevant institutional, national, and international guidelines legislation.

\section{Consent for publication}

Not applicable.

\section{Competing interests}

The authors declare that they have no known competing interests.

\section{Author details}

${ }^{1}$ Molecular Biology and Protein Science Laboratory, Department of Genetic Engineering and Biotechnology, University of Rajshahi, Rajshahi 6205, Bangladesh. ${ }^{2}$ Molecular Plant Physiology Laboratory, Department of Botany, University of Rajshahi, Rajshahi 6205, Bangladesh. ${ }^{3}$ Plasma Science and Technology Laboratory, Department of Electrical and Electronic Engineering, University of Rajshahi, Rajshahi 6205, Bangladesh. ${ }^{4}$ Department of Genetics, Faculty of Agriculture, University of Alexandria, Alexandria 21545, Egypt. ${ }^{5}$ Department of Biotechnology, College of Science, Taif University, P.O. Box 11099, Taif 21944, Saudi Arabia.

Received: 13 Auqust 2021 Accepted: 25 November 2021

Published online: 31 January 2022

References

1. Rahman MM, Sajib SA, Rahi MS, Tahura S, Roy NC, Parvez S, et al. Mechanisms and signaling associated with LPDBD plasma mediated growth improvement in wheat. Sci Rep. 2018;8(1):1-11.

2. Ling $L$, Jiafeng J, Jiangang $L$, Minchong $S$, Xin $H$, Hanliang $S$, Yuanhua $D$. Effects of cold plasma treatment on seed germination and seedling growth of soybean. Sci Rep. 2014;4(1):1-7.

3. Mony SA, Haque MS, Karim MA, Roy SK. Callus induction and plantlet regeneration in blackgram (Vigna mungo L. Hepper). Progress Agric. 2008;19(2):27-35.

4. Nyirenda $\mathrm{H}$. Achieving sustainable agricultural production under farmer conditions in maize-gliricidia intercropping in Salima District, central Malawi. Heliyon. 2019;5(10):e02632.

5. Karmakar S, Billah M, Hasan M, Sohan SR, Hossain MF, Hoque KM, et al. Impact of LFGD (Ar+ O2) plasma on seed surface, germination, plant growth, productivity and nutritional composition of maize (Zea mays L.). Heliyon. 2021;7(3):e06458.

6. Saberi M, Modarres-Sanavy SA, Zare R, Ghomi H. Amelioration of photosynthesis and quality of wheat under non-thermal radio frequency plasma treatment. Sci Rep. 2018;8(1):1-8.

7. Sajib SA, Billah M, Mahmud S, Miah M, Hossain F, Omar FB, et al. Plasma activated water: the next generation eco-friendly stimulant for enhancing plant seed germination, vigor and increased enzyme activity, a study on black gram (Vigna mungo L.). Plasma Chem Plasma Process. 2020;40(1):119-43.

8. Ling L, Jiangang L, Minchong S, Chunlei Z, Yuanhua D. Cold plasma treatment enhances oilseed rape seed germination under drought stress. Sci Rep. 2015;5(1):1-10.

9. Dobrynin D, Fridman G, Friedman G, Fridman A. Physical and biological mechanisms of direct plasma interaction with living tissue. New J Phys. 2009;11(11):115020.

10. Dhayal M, Lee SY, Park SU. Using low-pressure plasma for Carthamus tinctorium L. seed surface modification. Vac. 2006;80(5):499-506.

11. Wu J, Lawit SJ, Weers B, Sun J, Mongar N, Van Hemert J, Melo R, Meng X, Rupe M, Clapp J, Collet KH. Overexpression of zmm28 increases maize grain yield in the field. Proc Natl Acad Sci. 2019;116(47):23850-8.

12. Yang Y, Xu W, Hou P, Liu G, Liu W, Wang Y, Zhao R, Ming B, Xie R, Wang K, Li S. Improving maize grain yield by matching maize growth and solar radiation. Sci Rep. 2019;9(1):1-11.

13. Sera B, Spatenka P, Serý M, Vrchotova N, Hruskova I. Influence of plasma treatment on wheat and oat germination and early growth. IEEE Trans Plasma Sci. 2010;38(10):2963-8.

14. Volin JC, Denes FS, Young RA, Park SM. Modification of seed germination performance through cold plasma chemistry technology. Crop Sci. 2000;40(6):1706-18.

15. Rafiei A, Sohbatzadeh F, Hadavi S, Bekeschus S, Alimohammadi M, Valadan R. Inhibition of murine melanoma tumor growth in vitro and in vivo using an argon-based plasma jet. Clin Plasma Med. 2020;19:100102. 
16. Jiang J, Lu Y, Li J, Li L, He X, Shao H, Dong Y. Effect of seed treatment by cold plasma on the resistance of tomato to Ralstonia solanacearum (bacterial wilt). PLoS ONE. 2014;9(5):e97753.

17. Ming-jing HU. Physiological effect of plasma on wheat seed germination. J Shanxi Agric Sci. 2010;11(9).

18. Los A, Ziuzina D, Boehm D, Cullen PJ, Bourke P. Investigation of mechanisms involved in germination enhancement of wheat (Triticum aestivum) by cold plasma: effects on seed surface chemistry and characteristics. Plasma Process Polym. 2019;16(4):1800148.

19. Wu ZH, Chi LH, Bian SF, Xu KZ. Effects of plasma treatment on maize seeding resistance. J Maize Sci. 2007;15:111-3.

20. Bormashenko E, Grynyov R, Bormashenko Y, Drori E. Cold radiofrequency plasma treatment modifies wettability and germination speed of plant seeds. Sci Rep. 2012;2(1):1-8.

21. Wojtyla $Ł$, Lechowska K, Kubala S, Garnczarska M. Different modes of hydrogen peroxide action during seed germination. Front Plant Sci. 2016;7:66.

22. Bailly C, El-Maarouf-Bouteau H, Corbineau F. From intracellular signaling networks to cell death: the dual role of reactive oxygen species in seed physiology. C R Biol. 2008;331(10):806-14.

23. Arasimowicz M, Floryszak-Wieczorek J. Nitric oxide as a bioactive signalling molecule in plant stress responses. Plant Sci. 2007;172(5):876-87.

24. Besson-Bard A, Astier J, Rasul S, Wawer I, Dubreuil-Maurizi C, Jeandroz S, Wendehenne D. Current view of nitric oxide-responsive genes in plants. Plant Sci. 2009;177(4):302-9.

25. Giba Z, Grubišić D, Konjević R. Seeking the role of NO in breaking seed dormancy. Nitric oxide in plant growth, development and stress physiology. Berlin, Heidelberg: Springer; 2006. p. 91-111.

26. Roy NC, Hasan MM, Talukder MR, Hossain MD, Chowdhury AN. Prospective applications of low frequency glow discharge plasmas on enhanced germination, growth and yield of wheat. Plasma Chem Plasma Process. 2018;38(1):13-28

27. Halliwell B, Foyer $\mathrm{CH}$. Properties and physiological function of a glutathione reductase purified from spinach leaves by affinity chromatography. Planta. 1978;139(1):9-17.

28. Alexieva V, Sergiev I, Mapelli S, Karanov E. The effect of drought and ultraviolet radiation on growth and stress markers in pea and wheat. Plant Cell Environ. 2001:24(12):1337-44.

29. Guy C, Haskell D, Neven L, Klein P, Smelser C. Hydration-stateresponsive proteins link cold and drought stress in spinach. Planta. 1992;188(2):265-70.

30. Kruger NJ. The Bradford method for protein quantitation. In The protein protocols handbook. Humana Press; 2009. p. 17-24.

31. Kabir AH, Rahman MM, Das U, Sarkar U, Roy NC, Reza MA, et al. Reduction of cadmium toxicity in wheat through plasma technology. PLOS ONE. 2019;14(4):e0214509.

32. Zeb A, Zahir A, Ahmad T, Abdumanon A. Physiochemical characteristics of wheat varieties growing in the same and different ecological regions of Pakistan. Pak J Biol Sci. 2006;9(9):1823-8.

33. Horwitz W, Chichilo P, Reynolds H. Official methods of analysis of the Association of Official Analytical Chemists. Official methods of analysis of the Association of Official Analytical Chemists. Benjamin Franklin Station; 1970.

34. Jiafeng J, Xin H, Ling LI, Jiangang L, Hanliang S, Qilai X, Renhong Y, Yuanhua D. Effect of cold plasma treatment on seed germination and growth of wheat. Plasma Sci Technol. 2014;16(1):54.

35. Kyzek S, Holubová L’, Medvecká V, Tomeková J, Gálová E, Zahoranová A. Cold atmospheric pressure plasma can induce adaptive response in pea seeds. Plasma Chem Plasma Proces. 2019;39(2):475-86.

36. Zhou Z, Huang Y, Yang S, Chen W. Introduction of a new atmospheric pressure plasma device and application on tomato seeds. Agric Sci. 2011;2(1):23-7.

37. Selcuk M, Oksuz L, Basaran P. Decontamination of grains and legumes infected with Aspergillus spp. and Penicillum spp. by cold plasma treatment. Bioresour Technol. 2008:99(11):5104-9.

38. Meiqiang $Y$, Mingjing $H$, Buzhou $M$, Tengcai $M$. Stimulating effects of seed treatment by magnetized plasma on tomato growth and yield. Plasma Sci Technol. 2005;7(6):3143.

39. Adhikari B, Adhikari M, Ghimire B, Adhikari BC, Park G, Choi EH. Cold plasma seed priming modulates growth, redox homeostasis and stress response by inducing reactive species in tomato (Solanum lycopersicum). Free Radic Biol Med. 2020;156:57-69.
40. Guo Q, Wang Y, Zhang H, Qu G, Wang T, Sun Q, Liang D. Alleviation of adverse effects of drought stress on wheat seed germination using atmospheric dielectric barrier discharge plasma treatment. Sci Rep. 2017;7(1):1-4.

41. Billah M, Karmakar S, Mina FB, Haque MN, Rashid MM, Hasan MF, Acharjee UK, Talukder MR. Investigation of mechanisms involved in seed germination enhancement, enzymatic activity and seedling growth of rice (Oryza Sativa L.) using LPDBD (Ar+ Air) plasma. Arch Biochem Biophys. 2021;698:108726

42. Kitazaki S, Koga K, Shiratani M, Hayashi N. Growth enhancement of radish sprouts induced by low pressure $\mathrm{O}_{2}$ radio frequency discharge plasma irradiation. Jpn J Appl Phys. 2012;51(1S):01AE01.

43. Henselová M, Slováková L’, Martinka M, Zahoranová A. Growth, anatomy and enzyme activity changes in maize roots induced by treatment of seeds with low-temperature plasma. Biologia. 2012;67(3):490-7.

44. Bethke PC, Badger MR, Jones RL. Apoplastic synthesis of nitric oxide by plant tissues. Plant Cell. 2004;16(2):332-41.

45. Mallick N, Mohn FH. Reactive oxygen species: response of algal cells. J Plant Physiol. 2000;157(2):183-93.

46. Planchet $E$, Jagadis Gupta K, Sonoda M, Kaiser WM. Nitric oxide emission from tobacco leaves and cell suspensions: rate limiting factors and evidence for the involvement of mitochondrial electron transport. Plant J. 2005;41(5):732-43.

47. Jeevan Kumar SP, Rajendra Prasad S, Banerjee R, Thammineni C. Seed birth to death: dual functions of reactive oxygen species in seed physiology. Ann Bot. 2015;116(4):663-8.

48. Noctor G, Mhamdi A, Chaouch S, Han Yl, Neukermans J, Marquez-Garcia BE, Queval G, Foyer CH. Glutathione in plants: an integrated overview. Plant Cell Environ. 2012;35(2):454-84.

49. Bashir K, Inoue H, Nagasaka S, Takahashi M, Nakanishi H, Mori S, Nishizawa NK. Cloning and characterization of deoxymugineic acid synthase genes from graminaceous plants. J Biol Chem. 2006;281(43):32395-402.

50. Pereira SI, Abreu D, Moreira H, Vega A, Castro PM. Plant growthpromoting rhizobacteria (PGPR) improve the growth and nutrient use efficiency in maize (Zea mays L.) under water deficit conditions. Heliyon. 2020;6(10):e05106.

51. Netshishivhe M, Omolola AO, Beswa D, Mashau ME. Physical properties and consumer acceptance of maize-baobab snacks. Heliyon. 2019;5(3):e01381.

52. Guzmán Mar JL, Hinojosa Reyes L, Mizanur Rahman GM, Kingston HS. Simultaneous extraction of arsenic and selenium species from rice products by microwave-assisted enzymatic extraction and analysis by ion chromatography-inductively coupled plasma-mass spectrometry. J Agric Food Chem. 2009;57(8):3005-13.

53. Ramos AC, Bertolazi AA, Dias T, Dobbs LB, Campostrini E, Eutróbio JF, Krohling CA. Ecophysiology of iron homeostasis in plants. 2017.

54. Abu BA, Raubenheimer JE, Van Den Berg VL. Iron-focussed nutritional status of mothers with children (6-59 months) in rural northern Ghana. Heliyon. 2020;6(6):e04017.

55. Nciizah AD, Rapetsoa MC. Micronutrient seed priming improves maize (Zea mays) early seedling growth in a micronutrient deficient soil. Heliyon. 2020;6(8):e04766.

56. Muhammad I, Muhammad I, Anwar S, Rehana B, Saeed A, Rehan N, Ijaz M Tauseef A. Physiochemical trace elements and protein profiling of different wheat varieties of Pakistani origin. Gold Res Thoughts. 2013;3(6).

57. Ikhtiar K, Alam Z. Nutritional composition of Pakistani wheat varieties. J Zhejiang Univ Sci B. 2007;8(8):555-9.

58. Bhanger Ml, et al. Physicochemical characteristics of some bread wheat. Asian J Plant Sci. 1993;1(2):520-3.

59. Fageer AS, El Tinay AH. Effect of genotype, malt pretreatment and cooking on in vitro protein digestibility and protein fractions of corn. Food Chem. 2004;84(4):613-9.

60. Alemayehu GF, Forsido SF, Tola YB, Teshager MA, Assegie AA, Amare E. Proximate, mineral and anti- nutrient compositions of oat grains (Avena sativa) cultivated in Ethiopia: implications for nutrition and mineral bioavailability. Heliyon. 2021;7(8):e07722.

61. Adeyeye A, Ajewole K. Chemical composition and fatty acid profiles of cereals in Nigeria. Food Chem. 1992;44(1):41-4.

\section{Publisher's Note}

Springer Nature remains neutral with regard to jurisdictional claims in published maps and institutional affiliations. 